Meta

Journal des traducteurs

Translators' Journal

\title{
Recepción de Constantin-François de Volney en España
}

\section{Carmen Ramirez}

Volume 64, numéro 1, avril 2019

URI : https://id.erudit.org/iderudit/1065333ar

DOI : https://doi.org/10.7202/1065333ar

Aller au sommaire du numéro

\section{Éditeur(s)}

Les Presses de l’Université de Montréal

ISSN

0026-0452 (imprimé)

1492-1421 (numérique)

Découvrir la revue

Citer cet article

Ramirez, C. (2019). Recepción de Constantin-François de Volney en España. Meta, 64(1), 165-193. https://doi.org/10.7202/1065333ar

\section{Résumé de l'article}

L'étude de la réception en Espagne de Volney s'avère inséparable de l'accueil de son oeuvre en France, notamment dans le cas des Ruines ou méditations sur les révolutions et les empires, objet de cette enquête. Les innombrables retouches de l'auteur ont supposé maintes variantes dans le texte et multiplié les éditions. Ces divers stades de l'écriture attestent de la pensée de l'homme et des profonds changements historiques de son temps, riche en événements politiques significatifs. Les Ruines, issues des forges révolutionnaires, révisées pendant le Directoire, corrigées au crépuscule de l'Empire, cristallisent une vaste réflexion sur l'histoire de l'Ancien Régime et sur les prémisses de l'État $\mathrm{du}$ " siècle nouveau ». Notre approche de la réception de Volney s'inscrit dans cette mouvance éditoriale des premières éditions des Ruines et de la Loi Naturelle et s'intéresse aux retombées correspondantes sur les traductions espagnoles, concrètement celle de 1819 (Londres), basée principalement sur l'édition française de 1817 (Paris) revue et corrigée par l’auteur.
Ce document est protégé par la loi sur le droit d'auteur. L’utilisation des services d’Érudit (y compris la reproduction) est assujettie à sa politique d'utilisation que vous pouvez consulter en ligne.

https://apropos.erudit.org/fr/usagers/politique-dutilisation/ 


\title{
Recepción de Constantin-François de Volney en España
}

\author{
CARMEN RAMIREZ \\ Universidad de Sevilla, Sevilla, España* \\ cramirez@us.es
}

\section{RÉSUMÉ}

L'étude de la réception en Espagne de Volney s'avère inséparable de l'accueil de son œuvre en France, notamment dans le cas des Ruines ou méditations sur les révolutions et les empires, objet de cette enquête. Les innombrables retouches de l'auteur ont supposé maintes variantes dans le texte et multiplié les éditions. Ces divers stades de l'écriture attestent de la pensée de l'homme et des profonds changements historiques de son temps, riche en événements politiques significatifs. Les Ruines, issues des forges révolutionnaires, révisées pendant le Directoire, corrigées au crépuscule de l'Empire, cristallisent une vaste réflexion sur l'histoire de l'Ancien Régime et sur les prémisses de l'État du «siècle nouveau». Notre approche de la réception de Volney s'inscrit dans cette mouvance éditoriale des premières éditions des Ruines et de la Loi Naturelle et s'intéresse aux retombées correspondantes sur les traductions espagnoles, concrètement celle de 1819 (Londres), basée principalement sur l'édition française de 1817 (Paris) revue et corrigée par l'auteur.

\section{ABSTRACT}

This study of the Spanish translations of Les Ruines ou méditations sur les révolutions et les empires by Volney is framed in the context of his work's reception in France. The author made many alterations to his text, thereby generating numerous text variants and different versions and editions. Those diverse writing stages also attest to the evolution of his thinking and the profound historical changes of his time, rich in major political events. Les Ruines, forged in the 1789 revolutionary process, revised during the Directory and corrected in the twilight of the Empire, is a concise and far-reaching reflection on the history of the Ancien Régime and the premises of the State in the new century. Our work on the reception of Volney considers the editorial complexity of the first editions of Ruines and Loi naturelle and is interested in the respective repercussions in the Spanish translations, specifically that of 1819 (London), mainly based, in this case, on the 1817 French edition (Paris), revised and corrected by the author.

\section{RESUMEN}

El presente estudio de las traducciones españolas de Les Ruines ou méditations sur les révolutions et les empires de Volney se enmarca en el ámbito de la recepción de su obra en Francia. El autor retocó en gran medida su texto generando de este modo numerosas variantes textuales y distintas versiones y ediciones. Estos diversos estadios de su escritura reflejan además la evolución de su pensamiento y los profundos cambios históricos de su tiempo, rico en acontecimientos políticos relevantes. Les Ruines se fraguan durante el proceso revolucionario de 1789, se revisan durante el Directorio, se corrigen antes del Imperio y cristalizan en una profunda reflexión sobre la historia del Antiguo Régimen y sobre las premisas del Estado del nuevo siglo. Nuestro trabajo sobre la recepción de Volney se inscribe en la complejidad editorial de las primeras ediciones de estas obras y se interesa por sus consecuencias en las traducciones españolas, concretamente en la traducción de 1819 (Londres), basada principalmente, en este caso, en la edición francesa de 1817 (París) revisada y corregida por el autor. 


\section{MOTS-CLÉS/KEYWORDS/PALABRAS CLAVE}

littérature française, Volney, réception, traduction, Espagne

French literature, Volney, reception, translation, Spain

literatura francesa, Volney, recepción, traducción, España

Los tronos más poderosos serán de nuevo destruidos, y las catástrofes más terribles recordarán a los hombres que no quebrantan en vano las leyes de la naturaleza, ni los preceptos de la sabiduría y de la verdad.

(Volney 1817/1819: 76)

\section{Introducción: Volney y las Ruines triunfantes}

Constantin-François de Chassebœuf [de la Giraudais, dit Boisgirais] (1757-1820), conde de Volney, es contemporáneo de la Revolución y de los cambios que se produjeron entonces en la sociedad francesa de final del siglo XVIII y principios del siglo XIX. Junto a Raynal y Condorcet, Volney es uno de los últimos testigos de la escuela enciclopedista. Este ideólogo polifacético es escritor y filólogo, historiador y orientalista, periodista y etnólogo, viajero y político (Daru 1820a; Bossange 1821; Pastoret 1843; Berger 1853; Séché 1899; Gaulmier 1951/1980). Así lo acredita su extensa obra (Volney 1821; Volney 1989-1998). Versátil para unos, oportunista republicano para otros, es variable incluso en sus estudios hasta cambiar Derecho por Medicina, entre 1775 y 1882 (Gaulmier 1951/1980: 27). Terminada su época universitaria parisina, el joven filósofo angevino no tarda en frecuentar los círculos eruditos y anticlericales de la señora de Helvétius y del barón d'Holbach. Inicia entonces una destacada carrera política y literaria. Emprende además un primer viaje a Oriente con apenas veinticinco años (1783). Poco después, es elegido diputado de la Asamblea Nacional (de 1789 a 1791) y es nombrado Director General de Agricultura y de Comercio en Córcega (de 1790 a 1793). A poco de su regreso, en plena época del Terror, es encarcelado durante diez meses. Evita la pena capital por el golpe de estado parlamentario del 9 termidor (27 de julio de 1794). Más tarde, apoyará el cesarismo del 18 brumario (9 de noviembre de 1799). Es miembro del Instituto Nacional de las Ciencias y de las Artes desde 1787 y profesor de historia en la recién creada Escuela Normal, en noviembre de 1794 (Chamrobert 1829/1834: 483). Se convierte en miembro del Instituto de Francia, en 1795, en la sección de ciencias morales y políticas, y en 1797, ingresa en la prestigiosa Sociedad Asiática de Calcuta. Por aquellas fechas, entre 1795 y 1798, reside en Estados Unidos ${ }^{1}$ y es nombrado miembro de la Sociedad Americana de Filosofía de Filadelfia el 20 de enero de 1797. Poco tiempo después regresa a Francia y se incorpora a distintas tribunas de poder en calidad de miembro de la Academia francesa (1803), senador conservador (1804), conde del Imperio (26 abril de 1808) y par de Francia, bajo la Restauración (1814).

En el campo de las letras, inicia su andadura con una polémica memoria de estudios, Mémoire sur la Chronologie d'Hérodote (Volney 1808b)2 . Le siguen dos libros de viajes escritos a su regreso de Oriente: Voyage en Syrie et en Égypte pendant les

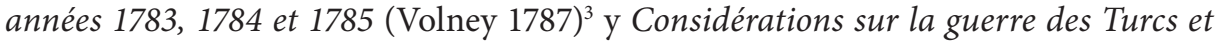
de la Russie (Volney 1788). Firma con su otro nombre: "Volney". En estos textos anuncia ya las meditaciones sobre ruinas e imperios que cristalizan en su obra maes- 
tra, Les Ruines ou Méditation sur les révolutions des empires, publicada en París, en agosto de $1791^{5}$. Obra con la cual homenajea a la Asamblea Nacional el 25 de septiembre (Rédaction du Journal de Paris 1791), poco antes de la aprobación de la primera Constitución liberal en Francia, abolida la monarquía absoluta (21 de septiembre de 1792). Tiempos convulsos en los que Volney pensó y escribió sobre el orden de la historia, la razón y la energía del progreso (Starobinski 1973; Benrekassa 1989; Koselleck 1979/1990; Lefranc 1993; Benjamin 1942/2000; Ginsberg 2004). El heredero de Voltaire traspasa los márgenes del "testament philosophique du XVIII siècle" (Gaulmier 1951/1980: 203). Reflexiona sobre la alianza política y cultural entre el legado ideológico europeo de las Luces y la historia política de los imperios orientales. Volney contrapone el despotismo, en todas sus variantes, ideológicas, políticas y religiosas, a la contemporánea legislación revolucionaria. Liquida pronto el tono elegiaco de la "Invocation" inicial (Volney 1817: 1-4) e impone una lúcida reflexión sobre el progreso, las libertades, la igualdad y la felicidad de los pueblos a escala universal.

Esta obra no tardó en cosechar un rotundo éxito a nivel nacional y europeo ${ }^{6}$. Desde su primera edición en 1791, las Ruines obtuvieron el favor de editores, traductores y lectores, especialmente hasta finales del siglo XIX. Contrariamente a lo que afirmaba Gaulmier (1951/1980: 233) acerca de la restrictiva lectura de las Ruines circunscrita a los años 1820-1830, nuestra propuesta de catálogo de ediciones y traducciones (véase los anexos) - con exclusión de las antologías - evidencia que esta obra se lee antes, durante y después de esta década. Lo confirman las ediciones más relevantes publicadas en esos periodos, entre las cuales cabe destacar las siguientes:

CUADRO 1

Las Ruines. Selección de ediciones francesas relevantes de finales del siglo XVIII y del siglo XIX

\begin{tabular}{|c|c|c|}
\hline Fecha de publicacion & Edición & Otros datos bibliográficos \\
\hline 1791 & Edición princeps & $\begin{array}{l}\text { París, Desenne, Volland, Plassan. } \\
\text { [Ilustraciones] }\end{array}$ \\
\hline 1792 & $\begin{array}{l}\text { Nueva edición corregida. } \\
\text { Segunda edición }\end{array}$ & $\begin{array}{l}\text { París, Desenne, Volland, Plassan. } \\
\text { [Ilustraciones] }\end{array}$ \\
\hline ca. 1792 & & $\begin{array}{l}\text { Bourg [-en-Bresse], Louis Hyacinthe Goyffon. } \\
\text { [Ilustraciones] }\end{array}$ \\
\hline $1795[1797]$ & Edición subrepticia & $\begin{array}{l}\text { Ámsterdam. Sin mención editorial. La fecha } \\
\text { impresa (1795) es falsa. La obra se imprimió en } \\
\text { Madrid, en las prensas de D. Benito García } \\
\text { Trío, en } 1797 \text { (Gil Ayuso 1932: 428). }\end{array}$ \\
\hline 1797 & Dos tomos & $\begin{array}{l}\text { Publicados por los Libraires associés. } \\
\text { [Ilustraciones] }\end{array}$ \\
\hline $1799 a$ & Tercera edición corregida & $\begin{array}{l}\text { Aumentada por primera vez con La loi } \\
\text { naturelle ou Catéchisme du citoyen français } \\
\text { (1793). París. A. J. Dugour y Durand. } \\
\text { [Ilustraciones] }\end{array}$ \\
\hline $1808 \mathrm{a}$ & Cuarta edición corregida & $\begin{array}{l}\text { Aumentada con Le Catéchisme du Citoyen } \\
\text { Français }^{7} \text {. París. Courcier. [Ilustraciones] }\end{array}$ \\
\hline 1817 & $\begin{array}{l}\text { Quinta edición cuidadosa- } \\
\text { mente corregida }\end{array}$ & $\begin{array}{l}\text { Añadida La loi naturelle. París, editorial de la } \\
\text { Veuve Courcier cuyo catálogo indica la } \\
\text { existencia de una traducción española (Lemaire } \\
\text { 1819: 15). }\end{array}$ \\
\hline
\end{tabular}




\begin{tabular}{|c|c|c|}
\hline 1820 & $\begin{array}{l}\text { Sexta edición corregida } \\
\text { nuevamente por el autor }\end{array}$ & $\begin{array}{l}\text { Añadida La loi naturelle. Editada en París por } \\
\text { los impresores Baudouin frères. Edición } \\
\text { provista de una noticia correspondiente al } \\
\text { discurso homenaje del conde de Daru (1820a: } \\
\text { 36-48) pronunciado en la sesión del } 14 \text { de junio } \\
\text { de } 1820 \text {, en la Cámara de los Pares, tras el óbito } \\
\text { de Volney ( } 25 \text { de abril de } 1820)^{8} \text { sobrevenido } \\
\text { durante el proceso de publicación. } \\
\text { [Ilustraciones]. Esta noticia necrológica (Daru } \\
\text { 1820b: i-xxj) alternará en sucesivas publicacio- } \\
\text { nes con otras noticias firmadas por Adolphe } \\
\text { Bossange (1821: I-XLIX), Jules Claretie (1868: } \\
\text { v-xxxix) o Eugène Berger (1870: I-XI). }\end{array}$ \\
\hline $\begin{array}{l}\text { 1821a, 1821b, } \\
1821 \mathrm{~d}\end{array}$ & $\begin{array}{l}\text { Primeras obras completas } \\
\text { revisadas por el autor }\end{array}$ & $\begin{array}{l}\text { París, Bossange frères. Noticia sobre Volney de } \\
\text { A. Bossange [Ilustraciones] }\end{array}$ \\
\hline $1821 \mathrm{c}$ & Séptima edición & $\begin{array}{l}\text { Añadida La loi naturelle. París, Bossange frères. } \\
\text { Noticia Noticia sobre Volney del conde Daru. } \\
\text { [Ilustraciones] }\end{array}$ \\
\hline $1822 \mathrm{a}$ & Décima edición & $\begin{array}{l}\text { Añadida La loi naturelle. París, Bossange frères. } \\
\text { Noticia sobre Volney del conde Daru. } \\
\text { [Ilustraciones] }\end{array}$ \\
\hline $1823 c, 1827 \mathrm{c}$ & $\begin{array}{l}\text { Trigésima y cuadragésima } \\
\text { ediciones }\end{array}$ & $\begin{array}{l}\text { Añadida La loi naturelle. Bruselas, Auguste } \\
\text { Wahlen. Noticia sobre Volney del conde Daru. } \\
\text { [Ilustraciones] }\end{array}$ \\
\hline $1823 a, 1823 b, 1823 d$ & Obras completas & $\begin{array}{l}\text { Bruselas, Auguste Wahlen. Noticia sobre } \\
\text { Volney del conde Daru. [Ilustraciones] }\end{array}$ \\
\hline 1824 & Nueva edición & París. Baudouin frères. [Ilustraciones] \\
\hline $\begin{array}{l}1825-1826 \\
1826 \mathrm{a}, 1826 \mathrm{~d}\end{array}$ & $\begin{array}{l}\text { Obras } \\
\text { Segunda edición completa }\end{array}$ & $\begin{array}{l}\text { Les ruines. La loi naturelle. París, Parmantier/ } \\
\text { Froment. Noticia sobre Volney de A. Bossange. } \\
\text { [Ilustraciones] }\end{array}$ \\
\hline $1826 b, 1826 c, 1826 \mathrm{e}$ & Obras escogidas & $\begin{array}{l}\text { Les ruines. La loi naturelle, L'Histoire de } \\
\text { Samuel. París. Baudouin frères. Noticia sobre } \\
\text { Volney del conde Daru. [Ilustraciones] }\end{array}$ \\
\hline $1827 \mathrm{a}, 1827 \mathrm{~b}, 1827 \mathrm{~d}$ & Obras escogidas & $\begin{array}{l}\text { Les ruines. La loi naturelle. Samuel. París. } \\
\text { Baudouin frères. Noticia sobre Volney del } \\
\text { conde Daru. [Ilustraciones] }\end{array}$ \\
\hline $1830 \mathrm{a}$ & Idéntica edición & $\begin{array}{l}\text { Añadida La loi naturelle. París/Bruselas, } \\
\text { Canongette. Noticia sobre Volney del conde } \\
\text { Daru. }\end{array}$ \\
\hline $1830 \mathrm{~b}$ & & $\begin{array}{l}\text { Añadida La loi naturelle. París/Bruselas, } \\
\text { Libraires associés/Librairie philosophique. } \\
\text { Noticia sobre Volney del conde Daru. }\end{array}$ \\
\hline 1832 & Nueva edición & $\begin{array}{l}\text { Añadida La loi naturelle. París, Lebigre frères. } \\
\text { En la contraportada se señala "Bruselas, A. } \\
\text { Wahlen". Noticia sobre Volney del conde Daru. } \\
\text { [Ilustraciones] }\end{array}$ \\
\hline 1833 & $\begin{array}{l}\text { Obras escogidas. Nueva } \\
\text { edición. }\end{array}$ & $\begin{array}{l}\text { Les ruines, La loi naturelle, Histoire de Samuel, } \\
\text { Lettres au Docteur Priestley. París, Lebigre } \\
\text { frères. Noticia sobre Volney de A. Bossange. } \\
\text { [Ilustraciones] }\end{array}$ \\
\hline 1836 & $\begin{array}{l}\text { Obras escogidas, Nueva } \\
\text { edición. }\end{array}$ & $\begin{array}{l}\text { Les ruines, La loi naturelle, Histoire de Samuel. } \\
\text { París, Lebigre frères. Noticia sobre Volney de A. } \\
\text { Bossange. [Ilustraciones] }\end{array}$ \\
\hline $1837 \mathrm{c}$ & Duoséptima edición & $\begin{array}{l}\text { Seguida de La loi naturelle. París/Bruselas, } \\
\text { Ledentu/Langlet y Cie. }\end{array}$ \\
\hline $1837 \mathrm{a}, 1837 \mathrm{~b}, 1837 \mathrm{~d}$ & Obras completas & $\begin{array}{l}\text { París, Firmin-Didot frères. Noticia sobre } \\
\text { Volney de A. Bossange. [Ilustraciones] }\end{array}$ \\
\hline
\end{tabular}




\begin{tabular}{|l|l|l|}
\hline $1839 a, 1839 b, 1839 c$ & Obras completas & $\begin{array}{l}\text { París, Auguste Desrez. Noticia sobre Volney de } \\
\text { A. Bossange. [Ilustraciones] }\end{array}$ \\
\hline 1846 & $\begin{array}{l}\text { Obras escogidas. Nueva } \\
\text { edición }\end{array}$ & $\begin{array}{l}\text { Les ruines, La loi naturelle, Histoire de Samuel, } \\
\text { París, B. Renault. Noticia sobre el autor. } \\
\text { [llustraciones] }\end{array}$ \\
\hline 1868 & $\begin{array}{l}\text { Nueva edición revisada a } \\
\text { la luz de los mejores textos }\end{array}$ & $\begin{array}{l}\text { Seguida de La loi naturelle y de L'Histoire de } \\
\text { Alonnier. Noticia sobre Volney por J. Claretie }\end{array}$ \\
\hline 1870 & Volney por E. Garnier frères. Noticia sobre \\
\hline $\begin{array}{l}\text { 1876d (1876a, 1876b, } \\
1876 c)\end{array}$ & Dos tomos en un volumen & $\begin{array}{l}\text { Les ruines y La loi naturelle. París, Librairie de } \\
\text { la Bibliothèque Nationale. Noticia sobre Volney. }\end{array}$ \\
\hline
\end{tabular}

A partir de entonces y hasta el final de la centuria, se mantiene el ritmo de ediciones, reimpresiones y tiradas de las Ruines y de la Loi naturelle en sucesivas entregas, recogidas en esta lista. Aunque parcial, esta enumeración da cuenta del significativo catálogo editorial de la obra maestra de Volney, de amplia difusión a pesar de las polémicas, las críticas y la severidad de la censura. Esta historia material (inconclusa) de las Ruines se completa con las numerosas traducciones en lengua inglesa, alemana, italiana, holandesa, árabe o española, publicadas desde principios del siglo XIX (Jullien 1819: 564).

\section{La recepción de Les ruines y de La loi naturelle en España}

La España decimonónica recibió las Ruines con rechazos y censuras. Por impía y funesta, se condenaba la obra de Volney al igual que se reprobaba los textos de d'Holbach, Marmontel, Rousseau, Bernadin de Saint Pierre, Llorente o Voltaire. Las fluctuaciones políticas, las mudanzas de los gobiernos y las variaciones ideológicas de la España borbónica, ilustrada, conservadora, carlista anticlerical, liberal, católica o no, como la España constitucionalista, o el reformismo burgués facilitaron y obstaculizaron a partes iguales la circulación de las nuevas ideas. A pesar de las corrientes conservadoras poco propicias al pensamiento de Volney, las Ruines de Palmire se convirtieron sin duda en la base del imaginario de las ruinas, y este en el salvaconducto de su triunfo literario. Este afortunado destino literario sepultaría en cierto modo la dimensión ideológica, sin ocultar no obstante la reflexión histórica y política en torno a las genealogías, a la ley y al poder revisados por el ideario revolucionario y sus nuevos códigos históricos, estéticos y culturales que inervaban la vieja Europa.

Éxito editorial que se extiende en España hasta las prensas madrileñas de la calle vieja de San Isidro en las que se imprime una edición francesa en 1797, fechada falsamente 1795 en pie de imprenta, con una tirada de setecientos cincuenta ejemplares (Gil Ayuso 1932: 429). Los impresores y libreros, Julián López, Benito García Trío, Manuel de Losada y Quiroga, entre otros muchos reos, fueron perseguidos y condenados, salvándose no obstante varios ejemplares de las llamas del "horno de la tahona de Lorenzo, Via de Madrid” (Gil Ayuso 1932: 428) permitiendo la impresión, y por tanto la difusión de esta edición. Había fallado la política de censura que no logró trabar el comercio de los libros prohibidos y aún menos silenciar las ideas procedentes de la Francia más revolucionaria. Esta edición subrepticia, reimpresión fraudulenta de la segunda edición de Volney (1792), sustanció una "escandalosa causa" 
(Meléndez Valdés 1832: lxv) de amplio alcance social. Trescientos noventa y cuatro folios relataron las causas y los hechos acontecidos de 22 de julio de 1797 a 27 de marzo 1798, fecha de la quema de los libros (Gil Ayuso 1932: 428-429).

Censores e inquisidores persiguieron y pohibieron esta obra a lo largo del siglo, antes y después del decreto de supresión definitiva del tribunal de la Inquisición (15 de julio de 1834), antes y después de las prerrogativas de las nuevas jurisdicciones de los llamados tribunales de la fe. Las Ruines fueron encausadas en reales audiencias y tribunales de censura desde que en 1797 el obispo de Salamanca detectara que "siendo este libro un tejido de máximas las más subversivas de los Estados y las más contrarias a la soberanía de los reyes, y de otras especies seductoras y detestables que sería menester borrar de la memoria de los hombres" (Gil Ayuso 1932: 429). La censura no tardó en operar en sus variados modos e incorporó la obra a sus muchos índices. En las distintas fases de la inquisición, los tribunales de fe y edictos varios, en España, en Italia, en Francia, impusieron idéntico y nefasto veredicto relativo a la Loi naturelle y en especial a las Ruines "notoriamente contraria[s] al dogma y destructora[s] de los fundamentos de la religión” (Higueruela del Pino 1980: 455-456). El índice de los libros prohibidos del año 1873 recoge las distintas prohibiciones dictaminadas por el Santo Oficio que afectan tanto la obra en francés como las traducciones, perfilando una significativa dimensión de la recepción de esta obra de finales del siglo XVIII hasta las postrimerías decimonónicas.

En el edicto de 2 de septiembre de 1797, el Santo oficio incluye la edición fraudulenta de las Ruines (Inquisición española 1805: 53), recogida aún en la edición de 1873 (Carbonero y Sol 1873: 669). Más tarde, la Sagrada Congregación del Índice prohibía Le Rovine, ossia meditazioni delle rivoluzioni degl'imperi quocumque idiomate, por decreto de 17 de diciembre de 1821 (Sacra Congregatio Indicis 1819: 350, 351; Sacra Congregatio Indicis 1822: 1) ${ }^{9}$. La Loi naturelle y las Ruines son prohibidas dos años después por el Deán y Cabildo de Toledo en el edicto de 12 de octubre de 1823 (Carbonero y Sol 1873: 405). Prohibición que aplica asimismo el Obispo de Oviedo, el 25 de marzo de 1824, extendiendo el Arzobispo de Valencia la interdicción, el 16 de octubre de 1825, a "Todas sus obras" (Carbonero y Sol 1873: 669), y el Obispo de Cuenca, el 22 de noviembre de 1825, a las ediciones "en todos los idiomas" (Carbonero y Sol 1873: 572). Finalmente, el Obispo de Osma, el 8 de julio de 1870 (Carbonero y Sol 1873: 572), firma el edicto que prohíbe las Ruinas de Palmira junto con otros varios libros considerados impíos y perversos, incluidos en la colección de la "Gran Biblioteca del Pueblo" editada por José Codina (Volney 1817/1868c).

"Una gran cantidad de libros obscenos, revolucionarioas e impíos", según un Real Acuerdo de la Audiencia de Asturias (7 de enero de 1826), traspasa frontera a lo largo del siglo (Calvo y Ayala 1826: 1-2), se disfrazan en ocasiones, y las Ruinas de Palmira ostentaron el curioso título de la Vida de San Miguel (Calvo y Ayala 1826: 3). Por otra parte, los contenidos de estas obras multiplican las polémicas originadas por la política inquisitorial del tiempo. En el caso que nos ocupa, el contenido religioso y político se convirtió desde el principio en el blanco de la Francia reaccionaria. Destacan en este sentido el controvertido Examen d'un écrit intitulé Les ruines, ou Méditations sur les Révolutions (Jouvin 1799), la famosa Réfutation du livre de Volney (Martin de Noirlieu 1823) y numerosas referencias en la prensa religiosa y política de la época. Incluso en ciertos casos, la virulencia de algunos artículos como aquellos publicados en Le Mémorial catholique (Bureau du Mémorial catholique 1825) fueron 
recogidos por la prensa española conservadora más afecta a la ortodoxia católica. Fue el caso de La Censura, revista que copió "un excelente pasaje" publicado en el Memorial catholique acerca de "obra tan pestilencial” (Villaseñor y Acuña 1845: 96). Las Ruines y la Loi naturelle conocieron por tanto una suerte similar en la España borbónica. En 1834, en sus Meditaciones, el arzobispo de Palmyra hacía apología de la verdad de la religión cristiana y refutaba "la impía fábula que forjó Volney" (Amat 1834: 1) y su visión materialista de la historia.

Este destino de querellas y prohibición no cercenó la amplia circulación de este libro cuya impresión continuó tanto en lengua francesa como en las traducciones en diferentes idiomas. En 1839, Quérard (274-275) ya había incluido las traducciones españolas (Volney 1817/1817b, 1817/1820a, 1817/1821) en su bibliografía de Volney. Asimismo, Palau (1976: 465-466), en su noticia sobre el ideólogo, estableció un catálogo de veinte títulos, datando las primeras traducciones españolas en París y Nueva York (Volney 1817/1817b, 1817/1817a), seguidas de las dos ediciones de Londres (Volney 1817/1818a, 1817/1819). Gaulmier (1951/1980: 236) reseñó algunos títulos del siglo XIX en lenguas italiana y alemana y solo cinco traducciones españolas. Por nuestra parte, hemos podido censar para el siglo XIX unas treinta traducciones destacables en lengua española (Véase Anexo 2). En las siguientes centurias, disminuye el ritmo de reediciones y traducciones, firmadas contemporáneamente por Juan Bautista Bergua, Armando Ruiz Gómez, J. Ribera, o P. López, siendo una de las últimas la edición de Demetrio Castro (Volney 1791/2018).

\section{La fortuna editorial de las traducciones}

Solo un año después de su edición princeps, salen a la luz las primeras traducciones de las Ruines. Datan de 1792 las versiones en lenguas alemana (Volney 1791/1792a, Berlín) y inglesa (Volney 1791/1792b, Londres) y de 1793, la anónima traducción americana de la Loi naturelle (Filadelfia). Las primeras traducciones en lengua española de ambas obras, conocidas hasta este momento, aparecen en los decenios iniciales del siglo XIX. Se publican anónimamente en 1817, en París (Volney 1817/1817b) y en Nueva York (Volney 1817/1817a); en 1818, en Londres (Volney 1817/1818a) y en París (Volney $1817 / 1818 b$ ), y en 1819, en Londres (Volney 1817/1819). La versión parisina de las Ruines, incluida la Loi naturelle (1817/1817b) se basa en la quinta y nueva edición publicada en las mismas prensas de la Viuda Courcier (Volney 1817). Presenta alguna variante significativa respecto a la edición tercera de 1799 y servirá, en general, de referencia ${ }^{10}$ para varias de las traducciones en lengua española, editadas o reeditadas más tarde. Es el caso de las dos traducciones del año 1818: una se corresponde con la traducción de Londres, impresa en T. Davidson (Volney 1817/1818a) y otra se publica en París, en la imprenta de M. Richard (1817/1818b). La traducción londinense de 1819 (Volney 1817/1819) no consigna nombre de autor, ni de traductor y carece de pie de imprenta. Rompe esta tendencia, la traducción de 1820 (Volney 1817/1820a) que firma el afrancesado José Marchena, reeditada en 1822 (Volney 1817/1822b). De su publicación se encargan las prensas de Pedro Beaume, en Burdeos. El original de referencia es la "última edición del original francés", según reza en la portada. El cotejo de ambos textos permite aclarar que la traducción de Marchena no coincide con la última edición del momento que se corresponde con la quinta edición (1817), sino que se ajusta también a versiones anteriores cuales son la tercera edición (1799) y la cuarta (1808). 
Estas primeras versiones en lengua española del siglo XIX constituyen parte de un repertorio de traducciones que recoge la tabla siguiente:

CUADRO 2

Las Ruines. Selección de traducciones españolas relevantes del siglo XIX

\begin{tabular}{|c|c|c|}
\hline Fecha de publicación & Edición & Otros datos bibliográficos \\
\hline $1817 / 1817 \mathrm{a}$ & $\begin{array}{l}\text { Traducción conforme a la } \\
\text { quinta edición de París }\end{array}$ & $\begin{array}{l}\text { Añadido el Catequismo de la ley natural. } \\
\text { Nueva York. Sin mención editorial. Láminas. }\end{array}$ \\
\hline $1817 / 1817 b$ & & $\begin{array}{l}\text { Añadida La ley natural. París, Mm[a] } \\
\text { Courcier. }\end{array}$ \\
\hline $1817 / 1818 \mathrm{a}$ & & $\begin{array}{l}\text { Incluida La ley natural. Londres, Imprenta } \\
\text { de T. Davidson. }\end{array}$ \\
\hline $1817 / 1818 b$ & & $\begin{array}{l}\text { Añadida La ley natural. París, Imprenta de } \\
\text { M. Richard. }\end{array}$ \\
\hline $1817 / 1819$ & & $\begin{array}{l}\text { Añadida La ley natural. Londres. Sin } \\
\text { mención editorial. }\end{array}$ \\
\hline $1817 / 1820 a$ & Nueva edición con notas & $\begin{array}{l}\text { Enriquecida con el Tratado de Ley Natural. } \\
\text { Perpiñán, José Alcine. }\end{array}$ \\
\hline $1817 / 1820 b$ & $\begin{array}{l}\text { Nueva traducción en } \\
\text { castellano de la última } \\
\text { edición del original francés } \\
\text { por D. Josef Marchena } \\
\end{array}$ & $\begin{array}{l}\text { Añadida La ley natural. Burdeos, Pedro } \\
\text { Beaume. Láminas. }\end{array}$ \\
\hline $1817 / 1821,1817 / 1822 c$ & & $\begin{array}{l}\text { Seguida de La ley natural. Madrid/París, en } \\
\text { casa de Rosa/gran Patio del Palacio Real. } \\
\text { Noticia necrológica por el S.r Daru. Láminas. }\end{array}$ \\
\hline $1817 / 1822 \mathrm{a}^{11}$ & $\begin{array}{l}\text { Traducción conforme a la } \\
\text { quinta edición de París }\end{array}$ & $\begin{array}{l}\text { Con el Catecismo de la ley natural. Nueva } \\
\text { York. Sin mención editorial. Láminas. }\end{array}$ \\
\hline $1817 / 1822 b$ & $\begin{array}{l}\text { Nueva traducción por Don } \\
\text { Josef Marchena. Segunda } \\
\text { edición }\end{array}$ & $\begin{array}{l}\text { Aumentada con La ley natural. Burdeos, } \\
\text { Pedro Beaume. Noticia sobre la vida y los } \\
\text { escritos de Volney. Láminas. }\end{array}$ \\
\hline $1817 / 1823$ & Sexta edición & $\begin{array}{l}\text { Añadida La ley natural. Madrid, Imprenta de } \\
\text { Sancha. Láminas. }\end{array}$ \\
\hline $1817 / 1835$ & Sexta edición & $\begin{array}{l}\text { Añadida La ley natural. París, Librería } \\
\text { Americana de Rosa. Noticias del conde de } \\
\text { Volney. Láminas. }\end{array}$ \\
\hline $1817 / 1836 a$ & & $\begin{array}{l}\text { Añadida La ley natural. París, Librería } \\
\text { Americana de Rosa. Noticias del conde de } \\
\text { Volney. Láminas. }\end{array}$ \\
\hline $1817 / 1836 b$ & $\begin{array}{l}\text { Comentada por D. B. F. A. } \\
\text { D.V. D. N. }\end{array}$ & $\begin{array}{l}\text { Seguida de La ley natural. París. Sin mención } \\
\text { editorial. Noticia necrológica por el señor } \\
\text { Daru. }\end{array}$ \\
\hline $1817 / 1836 c$ & & $\begin{array}{l}\text { Seguida de La ley natural. París, gran Patio } \\
\text { del Palacio Real. Noticia necrológica por el } \\
\text { Señor Daru. Láminas. }\end{array}$ \\
\hline $1817 / 1839 a$ & & $\begin{array}{l}\text { Añadida La ley natural. Zaragoza, Imprenta } \\
\text { de D. Felipe Sanz. Noticias del conde de } \\
\text { Volney. Láminas. }\end{array}$ \\
\hline $1817 / 1839 b$ & & $\begin{array}{l}\text { Añadida La ley natural. París, gran Patio del } \\
\text { Palacio Real. Noticia necrológica por el } \\
\text { Señor Daru. Láminas. }\end{array}$ \\
\hline$? / 1842^{12}$ & $\begin{array}{l}\text { Nueva traducción por Don } \\
\text { Josef Marchena }\end{array}$ & $\begin{array}{l}\text { Añadida La ley natural. París, Imprenta de } \\
\text { Panckoucke. }\end{array}$ \\
\hline $1817 / 1844,1817 / 1858$ & & $\begin{array}{l}\text { Adicionada con La ley natural. Perpiñán. Sin } \\
\text { mención editorial. Noticias del conde de } \\
\text { Volney. Láminas. }\end{array}$ \\
\hline
\end{tabular}




\begin{tabular}{|c|c|c|}
\hline $1817 / 1854$ & & $\begin{array}{l}\text { Seguida de La ley natural. Madrid, Imprenta } \\
\text { del editor. Biografía del conde de Volney. }\end{array}$ \\
\hline 1817/ca. 1868 & & $\begin{array}{l}\text { Seguida de La ley natural. Madrid, Domingo } \\
\text { Blanco. }\end{array}$ \\
\hline $\begin{array}{l}1817 / 1868 \mathrm{a} \\
1817 / 1868 \mathrm{~b} \\
1817 / 1868 \mathrm{c}\end{array}$ & Dos tomos en un volumen. & $\begin{array}{l}\text { Volney: Las Ruinas. La ley natural. } \\
\text { Barcelona, José Codina. "Gran Biblioteca del } \\
\text { Pueblo". Láminas. }\end{array}$ \\
\hline $1817 / 1869 a$ & & $\begin{array}{l}\text { Adicionada con La ley natural. Barcelona, } \\
\text { Establecimiento tipográfico-editorial de } \\
\text { Manero. Noticias del conde de Volney. } \\
\text { Láminas. }\end{array}$ \\
\hline $1817 / 1869 b$ & Traducción de A. O. A. & $\begin{array}{l}\text { Adicionada con La ley natural. Barcelona, } \\
\text { Sociedad literaria-editorial Guttemberg. } \\
\text { Láminas. }\end{array}$ \\
\hline $1817 / 1869 c$ & & $\begin{array}{l}\text { Seguida de La ley natural. Madrid, Imprenta } \\
\text { de Pascual Gracía y Orga. Introducción } \\
\text { sobre Volney }{ }^{13} \text {. }\end{array}$ \\
\hline 1817/ca. 1873 & Tercera edición & $\begin{array}{l}\text { Con La ley natural. Barcelona, José Codina. } \\
\text { "Gran Biblioteca del Pueblo". }\end{array}$ \\
\hline 1817/ca. 1880 & & $\begin{array}{l}\text { Seguida de La ley natural. Madrid, Imprenta } \\
\text { Plaza Dos de Mayo. }\end{array}$ \\
\hline $1817 / 1887$ & $\begin{array}{l}\text { Versión castellana revisada y } \\
\text { anotada por Cristóbal Litrán }\end{array}$ & $\begin{array}{l}\text { Con La ley natural. Barcelona, } \\
\text { Establecimiento editorial de V. Acha. } \\
\text { Láminas. }\end{array}$ \\
\hline $1817 / 1889$ & $\begin{array}{l}\text { Traducción de Emilio Prieto } \\
\text { y Villarreal }\end{array}$ & $\begin{array}{l}\text { Seguida de La ley natural y La historia de } \\
\text { Samuel. París, Garnier hermanos. }\end{array}$ \\
\hline $1817 /$ ca. $1892^{14}$ & $\begin{array}{l}\text { Traducción de A. Zeugeid } \\
\text { Edición popular }\end{array}$ & $\begin{array}{l}\text { Seguida de La ley natural. Barcelona, edición } \\
\text { de A. Zeugeid. Láminas. }\end{array}$ \\
\hline
\end{tabular}

De los datos de este catálogo se desprende, por un lado que la mayoría de las traducciones no están firmadas, con excepción de los textos de E. Prieto y Villarreal, A.O.A, José Marchena, Cristóbal Litrán, A. Zeugeid, siendo estos tres traductores los más relevantes. La traducción de A. Zeugeid (Volney 1817/ca.1892), pseudónimo de Andrés Diéguez, traductor y editor ${ }^{15}$, será reeditada en varias ocasiones a lo largo del siglo XX. En cuanto a Cristóbal Litrán, políglota y acendrado traductor, librepensador, republicano, columnista, hombre de alta cultura y fuerte compromiso político $^{16}$, no podía no traducir las Ruines (Volney 1817/1887). Las versiones de Litrán y Diéguez, oportunamente revisada la ortografía, se inscriben en la línea primera de las traducciones publicadas a principios de siglo XIX, la de 1819 incluida. La versión del escritor y traductor José Marchena constituye, sin embargo, un punto de inflexión en el corpus volneano español. Afrancesado afecto a las ideas revolucionarias, de pluma ágil, en español y en francés, su traducción (Volney 1817/1820a) presenta por un lado, una escritura más elaborada y por otra parte, numerosas variaciones y aminoraciones con respecto al original (Durnerin 2004: 95-106; Ramírez 1999: 55-58). Marchena ya había declarado que: "No es traducir ceñirse a poner en una lengua los pensamientos o los afectos de un autor que los ha expresado en otra. [...]" (Montesquieu 1721/1818: 323).

En todos los casos, con esta traducción de Volney, Marchena enriquecía su extenso catálogo de polémicas traducciones de grandes pensadores e ideólogos franceses del siglo XVIII tales como Montesquieu, Voltaire, Rousseau, A. V. Benoît o Ch-F. Dupuis (Lafarga 2009: 754-756) y aportaba los contrastes necesarios al repertorio de traducciones decimonónicas de las Ruines. 
Por otro lado, los lugares de publicación son España (Barcelona, Madrid, Zaragoza), Francia (Burdeos, París, Perpiñán), Inglaterra (Londres) y Estados Unidos (Filadelfia y Nueva York).

Observamos además que, contrariamente a algunas afirmaciones ${ }^{17}$, las traducciones españolas se han impreso y reimpreso indistintamente durante los reinados de Fernando IV (1803-1833), Isabel II (1833-1868), el Sexenio Revolucionario y la primera república (1868-1874), y la restauración de la monarquía (1875-1902). Recordemos por otra parte que Volney revisó y corrigió su texto entre 1791 y $1817^{18}$, es decir, desde la revolución de 1789 hasta la era posnapoleónica. Por tanto, invitaba a su lectura a detractores y defensores de todas las suertes ideológicas y culturales, liberales, laicos, o católicos, conservadores o integristas, aristócratas, constitucionalistas y republicanos. Por consiguiente, tanto el autor como los traductores, de algún modo, aseguraban la continuidad y la evolución del texto y de sus cambios, colaborando al complejo proceso de creación y de recepción literaria, y en este caso de transmisión de ideas.

Respecto al principal texto de referencia propuesto (Volney 1817), la disposición textual no presenta variaciones significativas. Sin embargo el título adopta formas distintas marcadas en parte o en su totalidad por la elipsis, la contracción, la inversión de los términos, variando en ocasiones para un mismo ejemplar entre cubierta, portadilla y portada.

CuAdRO 3

Títulos españoles de las Ruines

\begin{tabular}{|l|l|}
\hline \multicolumn{1}{|c|}{ Fechas de publicación } & \multicolumn{1}{c|}{ Títulos } \\
\hline $1817 / 1817 \mathrm{a}, 1817 / 1822 \mathrm{a}, 1817 / 1858$ & Las ruinas \\
\hline $\begin{array}{l}1817 / 1817 \mathrm{~b}, 1817 / 1818 \mathrm{a}, 1817 / 1818 \mathrm{~b}, 1817 / 1819, \\
1817 / 1821,1817 / 1822 \mathrm{c}, 1817 / 1836 \mathrm{c}, 1817 / 1868 \mathrm{~b}\end{array}$ & Meditación sobre las ruinas \\
\hline $\begin{array}{l}1817 / 1820 \mathrm{a}, 1817 / 1820 \mathrm{~b}, 1817 / 1821,1817 / 1822 \mathrm{c}, \\
1817 / 1822 \mathrm{~b}, 1817 / 1823,1817 / 1836 \mathrm{~b} 1817 / 1836 \mathrm{c}, \\
? / 1842,1817 / 1844,1817 / 1854,1817 / 1858,\end{array}$ & $\begin{array}{l}\text { Las ruinas, ó Meditación sobre las revoluciones } \\
\text { de los imperios }\end{array}$ \\
\hline $1817 / 1869 \mathrm{c}$ & \\
\hline $\begin{array}{l}1817 / 1835,1817 / 1836 \mathrm{a}, 1817 / 1839 \mathrm{a}, 1817 / 1839 \mathrm{~b}, \\
1817 / \mathrm{ca} .1868,1817 / 1868 \mathrm{~b} 1817 / 1869 \mathrm{a},\end{array}$ & $\begin{array}{l}\text { Las ruinas de Palmira [,] [ó] meditación sobre las } \\
1817 / 1869 \mathrm{~b}, 1817 / \mathrm{ca} .1873,1817 / \mathrm{ca} .1880,1817 / \text { ca. } \\
1892\end{array}$ \\
\hline $\begin{array}{l}\text { 1817/1868b } 1817 / 1869 \mathrm{a}, 1817 / 1887,1817 / 1889, \\
1817 / \mathrm{ca} .1892\end{array}$ & Las ruinas de Palmira \\
\hline
\end{tabular}

A partir de la tercera edición (Volney 1799a), el texto de las Ruines lleva normalmente aparejado la Loi naturelle, ou Principes physiques de la morale, déduits de l'organisation de l'homme et de l'univers. Titulo que, en español, conoce variantes marcadas también por elipsis parcial o total y por cambios varios: 
CUADRO 4

Títulos españoles de la Loi naturelle

\begin{tabular}{|c|c|}
\hline Fechas de publicación & Títulos \\
\hline $\begin{array}{l}\text { 1817/1817b, 1817/1818a, 1817/1818b, 1817/1819, } \\
\text { 1817/1820a, 1817/1821, 1817/1822b, 1817/1822c, } \\
\text { 1817/1823, 1817/1835, 1817/1836a, 1817/1836b, } \\
\text { 1817/1836c, 1817/1839a, 1817/1839b, ?/1842, } \\
\text { 1817/1844, 1817/1854, 1817/1858, 1817/ ca. } 1868, \\
\text { 1817/1868a, } 1817 / 1869 \mathrm{a}, 1817 / 1869 \mathrm{~b}, 1817 / 1869 \mathrm{c}, \\
\text { 1817/ ca. } 1873,1817 / \mathrm{ca} .1880,1817 / 1887, \\
\text { 1817/1889, } 1817 / \text { ca. } 1892\end{array}$ & $\begin{array}{l}\text { La ley natural, ó Principios físicos de la moral, } \\
\text { [deducidos de la constitución del hombre y del } \\
\text { universo] }\end{array}$ \\
\hline 1817/1817a, 1817/1822a & $\begin{array}{l}\text { El Catequismo de la ley natural o } \\
\text { El catecismo de la ley natural }\end{array}$ \\
\hline $\begin{array}{l}\text { 1817/1820a, 1817/1821, 1817/1822b, 1817/1822c, } \\
\text { 1817/1823, 1817/1835, 1817/1836c, 1817/1836a, } \\
\text { 1817/1836b, 1817/1839a, 1817/1839b, ?/1842, } \\
\text { 1817/1844, 1817/1854, 1817/1858, 1817/ca. 1868, } \\
\text { 1817/1869a, 1817/1869b, 1817/ 1869c, 1817/ ca. } \\
\text { 1873, } 1817 / \text { ca.1880, 1817/1887, 1817/1889, 1817/ } \\
\text { ca. } 1892\end{array}$ & La ley natural \\
\hline 1817/1820a & Tratado de Ley Natural \\
\hline
\end{tabular}

Pero, ciertamente las Ruines de Palmire, el título "fabricado" por editores, lectores y traductores, será el que arraigue en España no solo como referencia bibliográfica para esa obra, sino como referente del universo simbólico de las ruinas en la época contemporánea (Mortier 1974; Benjamin 1942/2000; Augé 2003; Ginsberg 2004; Onfray 2010).

\section{La (olvidada) traducción de Londres (1819): datos para un estudio}

En este marco histórico y editorial complejo se inscribe la traducción londinense de 1819. Esta versión conoció una especial difusión y es representativa de las primeras traducciones españolas basadas en la quinta edición "soigneusement corrigée par l'auteur" (Volney 1817). Sin embargo, la traducción de J. Marchena en su edición de 1820 (Volney 1817/1820b) es la versión española más conocida y referenciada y que inspiró varias reediciones contemporáneas (Edaf, Museo universal).

El título de portada y portadilla de la traducción de Londres 1819 se ha reducido a Meditación sobre las ruinas. Al eliminar la segunda parte "revolución de los imperios" se desplaza el objeto de la meditación, hacia el efectismo romántico de las "ruines ruinées" (Gautier 1865: 322) y del memento mori de las "ruines" soslayando a priori la analogía volneana entre ruina, revolución e historia. Volney entendía el ámbito de la devastación como yacimiento del progreso y el declive de tiranías e imperios como parte de la construcción social y de la trama política de las sociedades nuevas, sujetas a la "ley natural".

Se ha eliminado también la cita del capítulo IV que acompaña el título en la práctica totalidad de las ediciones francesas ${ }^{19}$. Este epígrafe aparece en la conocida traducción de Marchena (Volney 1817/1820b) y en la traducción de 1823 (Volney 1817/1823). En su lugar, gran parte de las traducciones españolas decimonónicas añaden una lacónica sentencia aristotélica "El principio de la sabiduría es el saber dudar"20.

La composición del libro ${ }^{21}$ recoge básicamente las distintas partes de la obra de referencia: la portada, la tabla de los capítulos con indicación de los párrafos. La 
misma tabla de capítulos se repite a final del ejemplar y precede un "Catálogo de los libros españoles que se hallan en Burdeos, en casa de Lawalle jóven y sobrino paseo de Tourny, $\mathrm{n}^{\circ}$ 20" y otra lista de "Ouvrages anglais" (Volney 1817/1819: 1-10), la "Invocación”, titulada “Introducción” en la edición de Barcelona (Volney 1817/1868b: 5-6), y los veinticuatro capítulos cuyos títulos son traducidos literalmente. A continuación, para el texto de la Ley natural, el editor incluye una portadilla propia con el título completo: La ley natural o Principios físicos de la moral, deducidos de la constitución del hombre y del universo. Sigue una "Advertencia del editor francés" (Volney 1817/1819: 343-345), adaptación del “Avertissement de l'éditeur" (Volney 1817: 255-258), centrado en las bonanzas de la moral sistematizada por la razón expuesta en este "librito" (Volney 1817/1819: 344). En cuanto al párrafo último, si bien Marchena (Volney 1817/1820b: 257) lo conservó, el traductor de la versión de 1817 (Volney 1817/1819: 343-344) eliminaba ese fragmento en cuyas líneas recordaba el título original Catéchisme du Citoyen français y el alcance europeo de la obra asimilada a una suerte de "catéchisme du bon sens et des honnêtes gens" (Volney 1817: 257). Tal vez para compensar esta omisión, el traductor añade una nota a pie de página (Volney 1817/1819: 343) corrigiendo una fecha (1793) e indicando un confuso lugar de edición (Estados Unidos) de la primera publicación de esta Advertencia ${ }^{22}$. Da paso a los doce capítulos de la Ley natural cuyos epígrafes no varían salvo el título del quinto "Des vertus individuelles" (Volney 1817: 280) que el traductor (Volney 1817/1819: 367) ha ampliado: "De las virtudes individuales, y de la sabiduría". El ejemplar consultado de la edición londinense de las Ruinas, al igual que otras versiones españolas, adolece del "Avis au relieur" (Volney 1791: ij; Volney 1792: [s.p.]; Volney ca. 1792: vj) y de las ilustraciones a las que se refieren sus indicaciones. Mapas y otros grabados que sí incluye la edición de referencia (Volney 1817) y que aparecen de forma aleatoria en los distintos textos originales y versiones ${ }^{23}$. Tampoco reproduce el interesante "Avertissement" de las ediciones francesas de 1791 (Volney 1791: vij-x) y 1792 (Volney 1792: ix-xij; Volney ca. 1792: v) titulado "Preface” en las ediciones en inglés finiseculares (Londres: Volney 1791/1792b: v-vi, Volney ?/1795: v-vi, Volney ?/1796a: v-vi; Nueva York: Volney ?/1796b: 3-4; Filadelfia: Volney ?/1799: 3-4) y parte del siglo $\mathrm{XX}$. En el prefacio se vincula el origen de este proyecto a su Voyage en Syrie (Volney 1791: vij) y se explica el alcance de las Ruines (Volney 1791: ix): “cet Ouvrage n'est point le fruit d'un esprit de perturbation, mais d'un amour réfléchi de l'ordre et de l'humanité". Del mismo modo, el último capítulo (XXIV) en la primera edición de las Ruines (Volney 1791: 320-330) anuncia las grandes líneas de la Loi naturelle (1793) que Volney consideró como la segunda parte de las Ruines rubricando incluso en su última página la explícita mención correspondiente de "Fin de la première Partie ou des Ruines" (Volney 1791: 330). La Loi naturelle se convertía a partir de 1799 en corolario de la obra mayor de Volney ${ }^{24}$.

Frente a estas supresiones respecto a la estructura original, la edición de 1819 conserva las "Notas. Para autorizar o explicar algunos pasajes del texto" (Volney 1817/1819: 404-440), que corresponden a las "Notes. Servant d'éclaircissements et d'autorités à divers passages du texte [des Ruines]" (Volney 1817: 318-367). Este denso sistema de anotación que combina notas a pie de página y notas finales, presenta las siguientes variaciones cuantitativas: 
CUADRO 5

Sistema de notas de la $5^{a}$ édición de las Ruines y de la correspondiente traducción de 1819

\begin{tabular}{|c|c|c|c|c|c|}
\hline \multirow{2}{*}{ Notas } & \multirow{2}{*}{ Tipo de modificación } & \multicolumn{2}{|c|}{ Volney 1817} & \multicolumn{2}{|c|}{ Volney $1817 / 1819$} \\
\hline & & $\#$ & Página & $\#$ & Página \\
\hline \multirow{17}{*}{$\begin{array}{l}\text { Notas a pie } \\
\text { de página }\end{array}$} & Conservación & 1 & 217 & 1 & 294 \\
\hline & \multirow{7}{*}{$\begin{array}{l}\text { Conversión a nota } \\
\text { final }\end{array}$} & 1 & 8 & 1 & \multirow{4}{*}{404} \\
\hline & & 1 & 10 & 1 & \\
\hline & & 1 & 11 & 1 & \\
\hline & & 1 & 13 & 1 & \\
\hline & & 1 & 14 & 1 & 404-405 \\
\hline & & 1 & 122 & 1 & 409 \\
\hline & & 2 & 199 & 2 & 422 \\
\hline & \multirow{9}{*}{ Eliminación } & 1 & 23 & \multirow{9}{*}{\multicolumn{2}{|c|}{ N/A }} \\
\hline & & 2 & 24 & & \\
\hline & & 1 & 47 & & \\
\hline & & 1 & 64 & & \\
\hline & & 1 & 124 & & \\
\hline & & 1 & 127 & & \\
\hline & & 1 & 135 & & \\
\hline & & 1 & 136 & & \\
\hline & & 1 & 147 & & \\
\hline \multicolumn{2}{|r|}{ TOTAL } & 19 & - & 9 & - \\
\hline \multirow{2}{*}{ Notas finales } & Conservación & 70 & & 70 & \\
\hline & Eliminación & 21 & & N/A & \\
\hline \multicolumn{2}{|r|}{ TOTAL } & 91 & - & 70 & - \\
\hline
\end{tabular}

\section{CUADRO 6}

Sistema de notas de la $5^{\mathrm{a}}$ édición de la Loi naturelle y de la correspondiente traducción de 1819

\begin{tabular}{|c|c|c|c|c|c|}
\hline \multirow{2}{*}{$\begin{array}{l}\text { Notas a pie de } \\
\text { página }\end{array}$} & \multirow{2}{*}{ Tipo de modificación } & \multicolumn{2}{|c|}{ Volney 1817} & \multicolumn{2}{|c|}{ Volney $1817 / 1819$} \\
\hline & & \# & Página & \# & Página \\
\hline \multirow{5}{*}{$\begin{array}{l}\text { Notas } \\
\text { explicativas }\end{array}$} & \multirow{5}{*}{ Conservación } & 1 & 259 & 1 & 347 \\
\hline & & 1 & 277 & 1 & 364 \\
\hline & & 1 & 297 & \multirow{2}{*}{2} & \multirow{2}{*}{384} \\
\hline & & 1 & 298 & & \\
\hline & & 1 & 306 & 1 & 392 \\
\hline \multicolumn{2}{|l|}{ TOTAL } & 5 & - & 5 & - \\
\hline \multirow{7}{*}{$\begin{array}{l}\text { Notas del } \\
\text { traductor }\end{array}$} & \multirow{7}{*}{ Incorporación } & \multirow{7}{*}{\multicolumn{2}{|c|}{ N/A }} & 1 & 343 \\
\hline & & & & 1 & 358 \\
\hline & & & & 1 & 368 \\
\hline & & & & 1 & 375 \\
\hline & & & & 1 & 387 \\
\hline & & & & 1 & 390 \\
\hline & & & & 1 & 401-402 \\
\hline \multicolumn{2}{|l|}{ TOTAL } & \multicolumn{2}{|c|}{-} & 7 & - \\
\hline
\end{tabular}


En ningún caso, el editor ha distinguido entre notas de autor y de traductor, desactivando el doble plano de autoría del traductor y del autor y omitiendo información específica de la edición original.

De forma general, en relación con esta voluminosa anotación, el texto español presenta variaciones cualitativas por reducción, ampliación, eliminación e incorporaciones que ilustran los siguientes ejemplos:

CUADRO 7A

Variaciones cualitativas del sistema de notas de las Ruinas (1819) respecto a la $5^{\text {a }}$ edición de las Ruines de 1817

\begin{tabular}{|l|l|l|l|}
\hline \multirow{2}{*}{ Tipos de variación } & \multicolumn{1}{|c|}{ Notas } & \multicolumn{2}{c|}{ Página } \\
\cline { 3 - 4 } & & \multicolumn{1}{c|}{$\begin{array}{c}\text { Volney } \\
(\mathbf{1 8 1 7 / 1 8 1 9})\end{array}$} \\
\hline Reducción & Palacios de Tebas & 26 & 29 \\
\hline Ampliación & Despotismo paternal & 49 & 61 \\
\hline \multirow{4}{*}{ Eliminaciones múltiples } & Precisiones geográficas & $\begin{array}{l}23,24[2 \text { notas], } \\
82\end{array}$ & $\begin{array}{l}26,28 \text { (2 notas), } \\
107\end{array}$ \\
\cline { 2 - 4 } & Precisiones histórico-bibliográficas & $47,82,147$ & $59,107,197$ \\
\cline { 2 - 4 } & $\begin{array}{l}\text { Religiones, fariseos, sectas varias, } \\
\text { Vichnou }\end{array}$ & 124,127 & 165,169 \\
\cline { 2 - 4 } & Mahoma, Ali, el Corán, el islam & $64,135,136$ & $82,181,182$ \\
\hline \multirow{2}{*}{$\begin{array}{l}\text { Elipsis causadas por la } \\
\text { supresión de textos e } \\
\text { ilustraciones }\end{array}$} & Mapamundi & 23 & 26 \\
\cline { 2 - 4 } & Revelación de Buda & 161 & 216 \\
\hline
\end{tabular}

CUADRO 7B

Variaciones cualitativas del sistema de notas de las Ruinas (1819) respecto a ediciones de las Ruines anteriores a 1817 y exentas en la $5^{\text {a }}$ edición

\begin{tabular}{|c|c|c|c|c|c|c|c|}
\hline \multirow{2}{*}{$\begin{array}{l}\text { Tipos de } \\
\text { variación }\end{array}$} & \multirow[b]{2}{*}{ Notas } & \multicolumn{6}{|c|}{ Página en Volney } \\
\hline & & 1791 & 1792 & ca. 1792 & $1799 a$ & 1817 & $\begin{array}{l}1817 / \\
1819\end{array}$ \\
\hline \multirow{3}{*}{ Incorporación } & $\begin{array}{l}\text { Conflictos } \\
\text { finiseculares entre } \\
\text { Turcos y Rusos }^{25}\end{array}$ & 1 & 1 & 1 & $5-6$ & - & 1 \\
\hline & $\begin{array}{l}\text { Constelación } \\
\text { Testudo }\end{array}$ & 203 & 152 & 120 & 121 & - & 205 \\
\hline & $\begin{array}{l}\text { Trinidad cristiana } \\
\text { y Demiurgos o } \\
\text { dios obrero }^{26}\end{array}$ & 279 & 209 & 166 & 282 & - & 286 \\
\hline \multirow[t]{2}{*}{ Exención } & $\begin{array}{l}\text { El influjo de } \\
\text { tumbas y } \\
\text { sepulcros regios } \\
\text { en Luis XIV }{ }^{27}\end{array}$ & - & - & - & 2 & - & - \\
\hline & $\begin{array}{l}\text { La inquisición } \\
\text { española }^{28}\end{array}$ & 193 & 145 & 114 & 179 & - & - \\
\hline
\end{tabular}

Otras cuestiones materiales marcan el ejemplar de esta edición. A pesar de algunas disimetrías, de forma general, la distribución de los párrafos no entorpece el 
discurso textual. El festival tipográfico de versalitas, mayúsculas y cursivas de la edición francesa se reproduce en gran medida en la traducción de 1819. Los usos interrogativos y exclamativos están perfectamente establecidos. La puntuación varía sensiblemente, adaptada a las pausas españolas: el traductor suele cambiar las numerosas comas de las enumeratio de Volney por una coordinación en la coda del periodo. Asimismo, utiliza los dos puntos explicativos en sustitución de las frases yuxtapuestas.

En relación con la ortografía, el traductor anónimo publica en Londres un texto que evidencia en parte una ortografía arcaica y fluctuante, ajena a los cambios apuntados en la Ortografía de 1800 y a la reforma ortográfica de la Real Academia Española de 1815.

En términos de acentuación, no faltan las formas correctas de acentuación: "sí, tétrico, útiles, último, quién, juzgó, Génesis” (Volney 1817/1819: v, v, vj, 12, 16, 89, 200), incluidos los monosílabos, “á, ó, é”, acentuados conforme al uso, a saber "las vocales cuando se hallaren solas formando partes de la oración, á fin de que no se pronuncien como unidas á la vocal que precede [...]" (RAE 1815: 80). Pero abundan a lo largo del texto los ejemplos de acentuación deficitaria, arbitraria e incorrecta:

\section{CUADRO 8}

Acentuación arcaizante en Volney (1817/1819)

\begin{tabular}{|c|c|c|c|c|}
\hline & Lexía & Página & Lexía & Página \\
\hline \multirow{9}{*}{$\begin{array}{l}\text { Acentuación } \\
\text { deficitaria y } \\
\text { arbitraria }\end{array}$} & corazon & $\mathrm{V}$ & segun & 19 \\
\hline & vengais & $\mathrm{Vj}$ & réptiles & 21 \\
\hline & apoderáron & 1 & pasion & 22 \\
\hline & mas & 3 & despues & 27 \\
\hline & habian & 3 & nacion & 46 \\
\hline & meditacion & 5 & razon & 67 \\
\hline & situacion & 11 & Kôran & 161 \\
\hline & éxîto & 16 & Salomon & 406 \\
\hline & ántes & 16 & & \\
\hline \multirow{11}{*}{$\begin{array}{l}\text { Acentuación } \\
\text { contraria a la } \\
\text { norma }\end{array}$} & \multicolumn{4}{|c|}{ Acentuación de la vocal que sigue la $x$ (RAE 1815: 54-55) } \\
\hline & reflexîones & 5 & éxîto & 16 \\
\hline & exîstió & 5 & & \\
\hline & \multicolumn{4}{|c|}{ Presencia del grupo acentuado $q \ddot{u}$} \\
\hline & obliqüamente & 28 & freqüentemente & 373 \\
\hline & \multicolumn{4}{|c|}{ Conservación de las voces con $c, k$ y $q u$} \\
\hline & Quando & $\mathrm{V}$ & quanto & 10 \\
\hline & qual & 3 & Koran & 89 \\
\hline & quartos & 3 & Alcoran & 159 \\
\hline & \multicolumn{4}{|c|}{$\begin{array}{l}\text { Uso del dígrafo ch por la } c \text {, sancionado en el Diccionario de } 1803 \text { (RAE: 2) y en el } \\
\text { Prólogo, distinguiéndose en } 1815 \text { (RAE: XII) la ch doble de las voces "en que no se } \\
\text { pronunciaba y podrá equivocarse con la ch como en Christo, Christiano [...]". }\end{array}$} \\
\hline & christiano & 87 & Christo & 296 \\
\hline
\end{tabular}

Los usos ortográficos son asimismo reveladores de un uso antiguo y sancionado por las nuevas reglas de la Academia española. A título de ejemplo, declinamos los siguientes casos. 
CUADRO 9

Ortografía arcaizante en Volney (1817/1819)

\begin{tabular}{|c|c|c|c|c|c|}
\hline \multicolumn{2}{|c|}{ Tipos de arcaísmo } & Lexía & Página & Lexía & Página \\
\hline \multirow{4}{*}{$\begin{array}{l}\text { Uso antiguo (RAE } \\
1791,1792 \text { y } 1803 \text { ) de } \\
\text { las consonantes } g \text { y } x\end{array}$} & \multirow{4}{*}{$g$ por $j$} & magestuosa & 5 & mujer(es) & 79 \\
\hline & & viagero & 13 & genízaro & 92 \\
\hline & & salvage & 39 & linage & 130 \\
\hline & & extrangeros & 56 & ropages & 163 \\
\hline \multirow{7}{*}{ Confusión entre $y, j$ y $x$} & Confusión entre $y \mathrm{y} j$ & Yesus & 296 & Jesus & 296 \\
\hline & \multirow{6}{*}{ Confusión entre $x$ y $j$} & $\operatorname{dexa}(n)$ & viij & vexado & 45 \\
\hline & & fixando & 1 & xefe(s) & 55 \\
\hline & & texido(s) & 6 & reduxo & 72 \\
\hline & & baxo & 7 & exemplo(s) & 76 \\
\hline & & luxo & 10 & páxaro(s) & 172 \\
\hline & & dixe & 12 & xugo(s) & 349 \\
\hline
\end{tabular}

Cabe destacar ese mismo descuidado tratamiento ortográfico, con grafía y acentuación heteróclita en los abundantes topónimos, gentilicios y nombres propios, en especial aquellos pertenecientes a la historia de las religiones que ocupan un lugar destacable en esta obra.

CUADRO 10

Ortografía arcaizante en topónimos, gentilicios y nombres propios en Volney (1817/1819)

\begin{tabular}{|l|l|c|l|c|}
\hline \multicolumn{1}{|c|}{ Typo de modificación } & \multicolumn{1}{c|}{ Lexía } & Página & \multicolumn{1}{c|}{ Lexía } & Página \\
\hline \multirow{5}{*}{ Grafía y acentuación heteróclita } & Egypto & 1 & Arabes & 27 \\
\cline { 2 - 5 } & Eufrates & 4 & Ceylan & 31 \\
\cline { 2 - 5 } & Tyro & 6 & Zoroastres & 166 \\
\cline { 2 - 5 } & Balbek & 8 & Demi-Ourgos & 284 \\
\cline { 2 - 5 } & Zwiderzée & 12 & buddismo & 294 \\
\cline { 2 - 5 } & Africa & 27 & Asyrios & 299 \\
\hline \multirow{5}{*}{ Alternancias de formas } & Palmira, & 2 & Cachemir, & 6 \\
& Palmyra & 32 & Kachemir & 404 \\
\cline { 2 - 5 } & Babylonia, & 31 & & 279 \\
& Babilonia & 90 & Júpiter, & 282 \\
\cline { 2 - 5 } & Thuléa & 6 & You-piter, & 429 \\
\hline
\end{tabular}

En último término, las divergencias gramaticales y léxico-semánticas que se detectan entre el texto original y el texto traducido constituyen un amplio catálogo de inversiones, disimetrías y transposiciones que ilustran el siguiente cuadro con una serie de ejemplos representativos: 
CuAdRO 11

Divergencias gramaticales y léxico-semánticas entre la quinta edición de las Ruines (Volney 1817) y la traducción española de Londres (Volney 1817/1819)

\begin{tabular}{|c|c|c|}
\hline Tipos de divergencia & Volney (1817) & Volney (1817/1819) \\
\hline \multirow{6}{*}{$\begin{array}{l}\text { Inversiones de } \\
\text { adjetivos y } \\
\text { explicitaciones }\end{array}$} & “esprit occupé de réflexions” (p. 7) & $\begin{array}{l}\text { “ocupado mi espíritu en serias } \\
\text { reflexiones" (p. 4) }\end{array}$ \\
\hline & “les feux de la terre embrasée” (p. 7) & “el fuego de la abrasada tierra" (p. 4) \\
\hline & "morne silence" (p. 8) & "silencio tan tétrico" (p. 6) \\
\hline & “morne silence” (p. 242) & “el más profundo silencio” (p. 329) \\
\hline & $\begin{array}{l}\text { "anciens peuples et leurs ouvrages" } \\
\text { (p. 11) }\end{array}$ & $\begin{array}{l}\text { "antiguos pueblos y sus obras } \\
\text { magníficas" (p. 9); }\end{array}$ \\
\hline & “cette ancienne population” (p. 11) & $\begin{array}{l}\text { "su antigua é inmensa población" } \\
\text { (p. 9) }\end{array}$ \\
\hline \multirow{15}{*}{$\begin{array}{l}\text { Disimetrías } \\
\text { semánticas y } \\
\text { aproximaciones } \\
\text { léxicas }\end{array}$} & “cœur” (p. 6, 8) & "mente" (p. 2, 5) \\
\hline & "un vaste silence" (p. 7) & "un silencio profundo" (p. 4) \\
\hline & "un vaste silence" (p. 130) & "un silencio general" (p. 174); \\
\hline & "rêverie" (p. 8) & “meditación" (p. 5) \\
\hline & "rêverie" (p. 11) & “meditaciones" (p. 9) \\
\hline & “funestes révolutions?” (p. 11) & “Tan funestos trastornos" (p. 9) \\
\hline & “des larmes et des soucis” (p. 12) & “inquietudes y lágrimas" (p. 11) \\
\hline & "races privilégiées" (p. 12) & “Castas privilegiadas" (p. 11) \\
\hline & “races saintes” (p. 19) & “castas santas" (p. 21) \\
\hline & "le charme de ma rêverie" (p. 13) & “el gusto de mi imaginación” (p. 12) \\
\hline & “de la vérité et de la raison” (p. 15) & “de la verdad y de la justicia” (p. 15) \\
\hline & "Bases solides" (p. 21) & “Bases permanentes" (p. 23) \\
\hline & “solitude" (p. 22) & “desierto" (p. 25) \\
\hline & "la sagesse des tombeaux" (p. 23) & "los secretos de las tumbas" (p. 25) \\
\hline & “de telles rêveries" (p. 139) & “despropósitos” (p. 186) \\
\hline $\begin{array}{l}\text { Transposiciones } \\
\text { morfo-sintácticas }\end{array}$ & "multitude vivante" (p. 8) & “multitud de vivientes" (p. 5-6) \\
\hline $\begin{array}{l}\text { Enumeración entre } \\
\text { comas y } \\
\text { coordinación }\end{array}$ & $\begin{array}{l}\text { "cette multitude de matelots, de } \\
\text { pilotes, de marchands, de soldats?" } \\
\text { (p. 10) }\end{array}$ & $\begin{array}{l}\text { “y esa multitud de marineros, de } \\
\text { pilotos, de mercaderes y soldados?" } \\
\text { (p. 8) }\end{array}$ \\
\hline Galicismo & “paysans arabes” (p. 7) & “paisanos árabes" (p. 3) \\
\hline & “air calme et serein” (p. 7) & “ayre en calma” (p. 4) \\
\hline Elipsis & $\begin{array}{l}\text { “[...] dont la chaîne remonte depuis } \\
\text { le dernier atome jusqu'aux astres les } \\
\text { plus élevés. Voilà ce qu’a révélé au lit } \\
\text { du trépas notre Boudah Somona } \\
\text { Goutama” (p. 161) }\end{array}$ & $\begin{array}{l}\text { “[..] cuya cadena sube desde el } \\
\text { último átomo hasta los mas elevados } \\
\text { planetas" (p. 215-216) }\end{array}$ \\
\hline
\end{tabular}

Aunque falta un estudio comparado completo de la historia de las traducciones de las Ruines y de la Loi naturelle de Volney, estas observaciones relativas a algunos aspectos materiales de la traducción anónima de 1819 componen un primer esbozo de algunas de las características del texto y sintetizan las marcas formales de este corpus de traducciones (Volney 1817/1817a, 1817/1817b, 1817/1818a, 1817/1818b, 1817/1819). En este sentido, la traducción de 1819 constituye un referente que precede la traducción de José Marchena (Volney 1817/1820b) cuya versión actualizará la dinámica textual y escritural de estas obras. 
En relación con la composición del texto, hemos destacado, por una parte, la intervención del traductor en la anotación, es decir en el campo conceptual y explicativo de Volney y por otra parte, la utilización, y por tanto el conocimiento, de otras ediciones del texto. Se acredita por otro lado, el uso arcaico de la ortografía y se evidencia la descuidada atención prestada a la edición de esta traducción cuya modernización de la lengua empezará a hacerse efectiva a partir de la reimpresión de 1822 (Volney 1817/1822b).

En cuanto a las abundantes divergencias sintácticas y léxico-semánticas estudiadas se enmarcan de un modo general en una tendencia del traductor a la literalidad, compensada por cierta sutileza estilística en determinados casos. Así frente a "la sagesse des tombeaux" (Volney 1817: 23) que celan los saberes, sus misterios y sus secretos, sus virtudes y sus vilezas, el traductor ha tomado la parte por el todo, descartando el saber esclarecedor y eligiendo los "secretos de las tumbas" (Volney 1817/1819: 24). El traductor ha optado en esta ocasión por una interpretación del contenido, contrastando con la habitual literalidad con la que procede.

Literalidad que resta al conjunto de la traducción de las Ruines y la Loi naturelle la poeticidad que distinguió concretamente la versión de José Marchena. Así lo puede ilustrar el siguiente caso: Volney alude a "la terre, nue d'habitants" (Volney 1817: 11) y deviene bajo la pluma de Marchena "yerma la tierra de moradores" (Volney 1817/1820b: 7), para simplemente describirse en la traducción anónima de 1819 como "la tierra, desnuda de habitantes" (Volney 1817/1819: 9). Ciertamente, la poetización de la traducción de Marchena aporta al texto original una vena lírica que Volney disipó en cada momento estando más acorde con el estilo depurado y no menos expresivo de la traducción de 1819.

A la postre, esta traducción produce un texto más descriptivo que narrativo, más explicativo y didáctico que lírico y emotivo, sin perder agudeza en la reflexión planteada por Volney. Sin duda en ocasiones la literalidad resta perspicuidad al estilo, pero no debilita la eficacia expresiva que contiene la obra original y que la traducción de 1819 conserva.

Por otra parte, la variabilidad de esta traducción no se puede deslindar del conocimiento de la historia editorial del original y de las variantes textuales que reflejan los estadios de la escritura y el devenir de la historia Así lo ilustra una sentencia volneana que sintetiza a la par el entusiasmo revolucionario de las primeras horas de la Asamblea constituyente y de la Declaración de los derechos humanos y la nueva ecuación del bien individual como garantía del bien público: "[...] nous ne voulons qu'être libres, et la liberté n'est que la justice” (Volney 1817: 101) se convierte en “[...] y solo queremos ser libres, y la libertad no es sino la justicia” (Volney 1817/1819: 134). Trasposición del traductor de la asimilación entre libertad y justicia que Volney no había contemplado en las primeras ediciones: "[...] nous ne voulons qu'être libres: nous le sommes!” (Volney 1799a: 125). Marchena, sin embargo, en su traducción, no manejó la variante textual de 1817 y optó, en este caso, por la fórmula primera traduciendo como sigue esta sentencia: "[...] pero solo queremos ser libres, y lo somos" (Volney 1799a/1817/1820b: 95). En este sentido la traducción de Londres (1819) recoge la evolución del pensamiento de Volney y de los acontecimientos históricos, y contribuye a completarla.

En ningún caso estas variaciones (ortográficas, sintácticas, léxico-semánticas) suponen la ilegibilidad del texto. Tampoco disminuyen la efectividad del sentido 
general de estas dos obras que rubricaban la caída del Antiguo Régimen, y en especial la crítica de una cultura del poder basada en las potencias divinas y tiránicas de una gobernanza unitaria y arbitraria.

\section{Conclusión}

La traducción anónima de 1819 de las Ruines ou méditation sur les révolutions des empires y de la Loi naturelle traslada a pesar de una ortografía arcaizante y una sintaxis más correcta que fluida, la reflexión volneana sobre la razón, el poder y la historia de los hombres y las mujeres, sus credos y sus dogmas a los que incorporaba la destrucción, junto a los valores de progreso y de razón.

Para Volney, y sus traductores no lo desmienten, la experiencia de la historia preclara y crítica de los modelos antiguos, no se detiene en una visión melancólica (Ehrard 1991, 1996) y fija los nuevos límites del sujeto moderno en su sola individualidad. Así lo declaraba el autor: "Sois l'arbitre de ton sort; je te remets ta destinée" (Volney 1817: 31). Así lo traducía el anónimo escritor de la traducción de 1819: "Sé tú mismo el árbitro de tu suerte, yo te entrego tu destino" (Volney 1817/1819: 36).

Rotunda traducción (Volney 1817/1819) que drena voces de anteriores versiones (Volney 1817/1817b, 1817/1817a, 1817/1818a, 1817/1818b) cuya base principal es la quinta edición revisada de Volney (1817). El ideólogo había investido en el discurso de las ruinas, la energía de la razón y lo despojaba de la "crédulité" y de la "certitude" (Volney 1799b: xiij). Sumaba a la destrucción de altares y tronos, la verdad y la sabiduría, "la libertad" y "la justicia” (Volney 1817/1819: 134), para fundamentar los estados modernos del "siglo nuevo" (Volney 1817/1819: 125) y la soberanía de "un pueblo libre y legislador" (Volney 1817/1819: 134) asistido por un legislador "[...] que separa el mundo de las ilusiones del de las realidades" (Volney 1817/1819: 340).

La traducción anónima de 1819 contribuye a difundir no solo el texto de Volney, sino también las ediciones que lo construyen. Al mismo tiempo circulaban las distintas traducciones de las que se había inspirado y las versiones que inspiraría, colaborando así a crear una comunidad traductiva compuesta por autores, editores, traductores, impresores, censores. Esta solidadridad textual entrelaza versiones y variantes, originales y repeticiones, elipisis y metáforas, y cohesiona la escritura de una lengua a otra, de un tiempo a otro, de unas culturas a otras, mitigando la fragmentación auctorial, las rupturas cronológicas, la tensión estilística y la variabilidad lingüística y escritural que caracterizan toda traducción y ejemplifica en este caso, la traducción de estas obras de Volney. En el caso concreto de la traducción de 1819, la suma de versiones, la superposición de voces y estilos, el enjambre de notas y paratextos, las variadas perspectivas por las que el traductor descarta, conserva, y transforma el texto original, permiten acotar mejor un texto y sus anotaciones, con una propuesta de lectura de Volney más ajustada a la escritura de sus relatos, de sus ideas y a la expresión de sus reflexiones.

En este sentido, la traducción de 1819 propicia el contacto entre ediciones originales y las diversas traducciones (las anteriores y las venideras), estableciendo lo que Volney denominó en el preliminar de su estudio de las lenguas orientales, "une affinité morale, une communication d'usages, de besoins, d'opinions, de mœurs [...]" (Volney 1794: 3). 


\section{NOTAS}

* Este trabajo se ha realizado en el marco del proyecto de investigación FFI2015-63748-P, financiado por el Ministerio de Economía y Competitividad.

1. En 1797, surge la controversia entre el teólogo J. Priestley (1797) que denuncia el ateísmo de las Ruines del letrado Volney. Su respuesta es une defensa de la razón frente a dogmas y revelaciones (Smith ca. 1920; Volney 1821e: 367-384; Gaulmier 1951/1980: 385-388).

2. En 1781, el joven Volney entregó a la Academia francesa esta memoria que publica bajo la firma "M. C." en el Journal des sçavans (enero de 1782). El profesor Larcher, especialista de Heródoto, se ofuscó por esta publicación que juzgó insuficiente (M. C. 1782: 22-40).

3. Obra que contó con innúmeras reediciones. El título se modifica más tarde para ajustarse a la cronología del periplo: Voyage en Égypte et en Syrie (Volney 1822b).

4. Según Gaulmier (1951/1980: 57), la primera referencia de este nuevo apellido data de 1785.

5. La edición del impresor Louis Hyacinte Goyffon (Volney ca. 1792), sin fecha, no sería de 1791 sino de 1792, según apunta el bibliógrafo Sirand (1851: 21).

6. Nuestro estudio sobre la recepción de Volney no contempla el ámbito hispanoamericano donde también se significó su fortuna editorial.

7. Una mala reimpresión [de la tercera] según Renouard (1819: 236).

8. El editor incluyó el siguiente aviso: "La République des lettres ayant eu le malheur de perdre M. de Volney, pendant le nouveau tirage de cet ouvrage, nous avons cru devoir rendre un dernier hommage à son illustre auteur, en joignant ici une Notice nécrologique, par M. le comte Daru, Pair de France, membre de l'Académie française" (Baudouin y Baudouin 1820: s.p.).

9. Esta edición de 1819 del Index librorum prohibitorum incluye apéndices añadidos después de la fecha de publicación original. Estos apéndices contienen, entre otros, referencias a libros prohibidos por decreto de la Sagrada Congregación del Indíce entre enero de 1820 y agosto de 1828.

10. La quinta edición de 1817 de la viuda Courcier es una fuente ineludible para estudiar y recomponer la historia material de las ediciones francesas y de las traducciones españolas de las Ruines de Volney. Sin menoscabo de otras ediciones francesas de referencia, y de su uso parcial o total por parte de los traductores, consignaremos, sin embargo, la edición parisina de 1817 como base referencial en nuestro estudio, especialmente circunscrito a la traducción londinense de 1819.

11. Esta edición neoyorquina incluye el siguiente epígrafe: "Dedicado a los pueblos nacientes de las Indias castellanas, a los jefes generosos que les guían a la Libertad. Puedan los errores e infortunios del mundo antiguo enseñar la sabiduría y felicidad al mundo nuevo! Por el autor" (Volney 1817/1822a: s.p.). Esta dedicatoria atribuida a Volney pertenece al Discurso de Angostura de Simón Bolivar de 15 de febrero de 1819.

12. Según se refiere en la Bibliographie de France (Pillet 1842: 569), las prensas parisinas de Panckoucke publican en 1842 una nueva traducción de las Ruines y de la Loi naturelle, de Marchena.

13. Peculiar edición que cuenta con una sintética introducción crítica de las Ruinas, titulada "Un recuerdo de Volney" (Volney 1817/1869c: iii-v).

14. La publicación manejada presenta las dos fechas (1891 y 1892) en portada y contraportada respectivamente.

15. Licenciado en filosofía y letras y profesor de lenguas en una academia filológica de Barcelona, desarrolla su vida profesional entre la mitad del siglo XIX y los primeros años del siglo XX (Rata Sabia 1892: 232).

16. Litrán (1860-1926) ha traducido una novela tan conocida como Carmen de Mérimée, amén de obras de Conan Doyle, Dostoievski, Gorki, Francis Bacon o Renan. Es un conocido colaborador y corresponsal de numerosos periódicos catalanes, de corte republicano y anticlerical. Véase RATÉs, Juan (1915): Cristóbal Litrán. El Motín. 17:2-3. Tambien Litrán, Cristóbal (1915): Autobiografía. El Motín. 17:1.

17. Es el caso de Romero Recio (2008) y de Durnerin (2004: 102-103) quien señalaba que las traducciones de esta obra solo se publicaron durante los gobiernos liberales $(1818,1820,1823,1836,1839$, 1854, 1869), considerando además que "Con el bienio progresista, en 1854, aparece la primera traducción española" (Durnerin 2004: 102-103). A este respecto, es preciso recordar que en 1821, se había publicado ya en Madrid una traducción española (Volney 1817/1821).

18. En las notas de Chronologie d'Hérodote, Volney (1808b: x) revelaba su preocupación por la corrección de sus obras y el conocimiento de la elaboración de los libros: "Le fait est, qu'il est arrivé ici l'un de ces accidents d'Imprimerie assez fréquents, et dont malheureusement mes ouvrages offrent d'autres exemples". 
19. El párrafo inicial se reduce a las dos primeras líneas a partir de la edición revisada de 1817: “J'irai vivre dans la solitude parmi les ruines; j’interrogerai les monuments anciens sur la sagesse des temps passés" (Volney 1817: 22).

20. Tal vez el traductor, o el editor, resumió la acerada crítica a religiones y poderes abusivos en esta frase; antítesis, por otra parte de la sentencia cristiana, "El pincipio de la sabiduría es el temor de Dios".

21. Uno de sus mayores detractores en España, el Filósofo arrinconado comenta justamente la edición londinense de la traducción de 1819. Sarcástica reseña en la que asimila el libro de Volney con "las luces de la recta razón, las tinieblas tan densas” (El Filósofo arrinconado 1823: 103). Divide y resume la obra en tres partes: "Las Meditaciones ("ateísmo"); La ley natural ("materialismo"); y las notas (“ambos monstruos”) (El Filósofo arrinconado 1823: 103-104).

22. “Avertissement de l'éditeur” incluido en la tercera edición (París, Volney 1799) y en la versión americana (Volney ?/1799).

23. El frontispicio rubricado por P[ietro-Antonio] Martini, "Méditation devant les ruines" se encuentra en las primeras ediciones (Volney 1791, 1792, ca. 1792, 1799a, 1808a y 1817). A partir de 1820, otros editores como Baudouin recurrirán de forma aleatoria a distintos grabados, entre otros, firmados por Berthon y [Pierre-Gabriel] Berthault, y por P. Tardieu.

24. La traducción neoyorquina de 1822 incluye una nota en este sentido: "El volumen de legislación general anunciado en esta ultima frase, no ha parecido: el autor ha solamente publicado su librito de la Ley natural, que puede considerarse como la base de todas las leyes, y que por este motivo añadimos después" (Volney 1817/1822a: 213).

25. Volney se ocupó de estos conflictos, sus orígenes y sus consecuencias en las Considérations sur la guerre actuelle des Turcs (1788). Por otra parte, respecto a esta nota, conviene indicar que se trata de una de las variantes de las Ruines (primer párrafo del capítulo I). A partir de la edición de 1817, Volney sustituye a los “Tartares-Nogaïs [...] chassés de la Krimée” (Volney 1791: 1; Volney 1792: 1; Volney ca. 1792: 1; Volney 1799a: 5) por "les Russes victorieux" (Volney 1817: 5), eliminando en dicha edición la nota a pie de página y final correspondientes a la fecha y a la explicación de la traición de un príncipe para facilitar la anexión de Crimea a Rusia por mandato de Catherine II "une femme chrétienne et reine" (Volney 1791: 1; Volney 1792: 1; Volney ca. 1792: 1; Volney 1799a: 5). En la edición de 1819 solo se conserva la parte de la fecha: "Es decir el año $1784 \mathrm{~d}$. J. C. y año 1198 de la hégira” (Volney 1819: 1, 404).

26. Para traducir "demiourgos ou grand ouvrier" (Volney 1817: 210, 211), Marchena utiliza "[demiurgos o grande] artífice” (Volney 1817/1820a: 211, 212).

27. El texto de la nota es el siguiente: "Ce fut parce que les clochers de Saint-Denis, tombeau des rois de France, se voyent du château de Saint-Germain, que Louis XIV quitta cette admirable situation, et alla s'établir dans les sauvages forêts de Versailles" (Volney 1799a: 2).

28. Por su parte, Marchena (Volney 1817/1820a: 146) tradujo estas voces como sigue: "el estandarte de los frailes dominicos".

\section{REFERENCIAS BIBLIOGRÁFICAS}

Augé, Marc (2003): Le temps en ruines. París: Galilée.

Benjamin, Walter (1942/2000): Sur le concept d'histoire. In: Walter Benjamin. Euvres. (Traducido del alemán por Maurice De Gandillac, Rainer Rochlitz et Pierre Rusch) Vol. 3. Folio. París: Gallimard, 427-443.

Benrekassa, Georges (1989): Poétique et politique de la régénération. Les ruines de Volney et le moment révolutionnaire. Bulletin bibliographique de France. 34(2-3):149-157.

Durnerin, James (2004): Las Ruinas de Palmira, en la traducción del abate Marchena. Anales de Filología Francesa. 12:95-106.

EHrARD, Jean (1991): Volney ou la Révolution mélancolique. In: Simone BernARD-Griffiths et Stéphane Michaud, eds. Révolutions, résurrections et avènements. Mélanges offerts à Paul Viallaneix. París: SEDES, 7-16.

EHRARD, Jean (1996): L'Histoire revisitée par la révolution: Condorcet et Volney. Mélanges de l'École française de Rome. Italie et Méditerranée. 108(2):445-456.

Gaulmier, Jean (1968): Chateaubriand et Volney. Annales de Bretagne. 75(3):570-578.

Gaulmier, Jean (1951/1980): L'idéologue Volney 1757-1820. Contribution à l'Histoire de l'Orientalisme en France. Ginebra: Slatkine. 
Gil Ayuso, Faustino (1932): Las Ruinas de Palmira: una edición francesa hecha en Madrid en 1797. Revista de la Biblioteca, Archivo y Museo. 9(36):428-438.

GinsBerg, Robert (2004): The Æsthetics of Ruins. Ámsterdam: Rodopi.

Higueruela del Pino, Leandro (1980): Los libros prohibidos durante el trienio liberal (18201823). Boletín Millares Carlo. 2:455-456.

Koselleck, Reinhart (1979/1990): Le Futur passé. Contribution à la sémantique historique des temps historiques. (Traducido del alemán por Jochen Нооск et Marie-Claire Ноock) París: Éditions EHESS.

Lafarga, Francisco (2009): José Marchena y Ruíz de Cueto. In: Francisco Lafarga y Luis Pegenaute, eds. Diccionario histórico de la traducción en España. Madrid: Gredos, 754-756.

LEFranc, Jean (1993): Volney: du mythe des ruines à la réalité des révolutions. In: Bernard Bourgeors et Jacques D'HondT, eds. La philosophie et la révolution française. (Colloque de la Société française de philosohie, París, 31 de mayo y 1-2 de junio de 1989). París: Vrin, 188-194.

Mortier, Roland (1974): La poétique des ruines en France: ses origines, ses variations de la Renaissance à Victor Hugo. Ginebra: Librairie Droz.

Onfray, Michel (2010): Métaphysique des ruines: la peinture de Monsu Desidero. París: Librairie générale française.

Palau y Dulcet, Antonio (1976): Manual del librero hispanoamericano. Vol. 27. Barcelona: Librería Anticuaria de A. Palau.

Ramírez Gómez, Carmen (1999): De juicios y advertencias de traductores españoles de letras francesas del siglo XVIII. Feijoo, Lista, Marchena, Maury, Moratín. In: Francisco Lafarga, ed. La traducción en España (1750-1830): lengua, literatura, cultura. Barcelona: Universidad de Lleida, 55-66.

Romero Recio, Mirella (2008): Traductions libérales d'histoire ancienne, un espace de liberté dans la pensée absolutiste hégémonique. Anabases. 7:35-55.

Sмith, Edgard F. (ca. 1920): Priestley in America 1794-1804. Filadelphia: P. Blakiston's Son \& Co.

Starobinski, Jean (1973): 1789, les emblèmes de la Raison. París: Flammarion.

\section{ANEXOS}

\section{Anexo 1: Catálogo de las principales ediciones de las Ruines (finales del siglo XVIII} y siglo XIX)

Volney, Constantin-François (1791): Les ruines, ou Méditation sur les révolutions des empires. $1^{a}$ ed. París: Desenne/Volland/Plassan.

Volney, Constantin-François (1792): Les ruines ou Méditation sur les révolutions des empires. $2^{a}$ ed. París: Desenne/Volland/Plassan.

Volney, Constantin-François (ca. 1792): Les ruines, ou Méditation sur les révolutions des empires. Bourg-en-Bresse: Louis Hyacinthe Goyffon.

Volney, Constantin-François (1793): La Loi naturelle ou catéchisme du citoyen français. París: Sallior.

Volney, Constantin-François (1795): Les ruines ou Méditation sur les révolutions des empires, par M. Volney, Député à l'Assemblée Nationale de 1789. Ámsterdam: [s.n.].

VolNey, Constantin-François (1797): Les ruines, ou Méditation sur les révolutions des empires. 2 vols. París: Les libraires associés.

Volney, Constantin-François (1799a): Les ruines, ou Méditation sur les révolutions des empires. Corrigée, et augmentée du Catéchisme du citoyen français, par le même auteur. $3^{a}$ ed. París: A. J. Dugour et Durand.

Volney, Constantin-François (1808a): Les ruines, ou Méditation sur les révolutions des empires. Corrigée, et augmentée du Catéchisme du Citoyen Français, par le même auteur. $4^{a}$ ed. París: Courcier. 
Volney, Constantin-François (1817): Les ruines, ou Méditation sur les révolutions des empires. Soigneusement corrigée par l'Auteur; on y a joint La loi naturelle. $5^{\mathrm{a}}$ ed. París: $\mathrm{M}^{\mathrm{me}}$ Veuve Courcier.

Volney, Constantin-François (1820): Les ruines, ou Méditation sur les révolutions des empires. Corrigée de nouveau par l'auteur; on y a joint La loi naturelle. $6^{a}$ ed. París: Baudouin frères.

Volney, Constantin-François (1821a): La loi naturelle, ou Principes physiques de la morale, déduits de l'organisation de l'homme et de l'univers. In: Euvres complètes de C.-F. Volney. Vol. 1. París: Bossange frères, 247-310.

Volney, Constantin-François (1821b): Les ruines, ou Méditation sur les révolutions des empires. In: Euvres complètes de C.-F. Volney. Vol. 1. París: Bossange frères, 3-245.

Volney, Constantin-François (1821c): Les ruines, ou Méditation sur les révolutions des empires. On y a joint La loi naturelle. $7^{\mathrm{a}}$ ed. París: Bossange frères.

Volney, Constantin-François (1821d): Cuures complètes de C.-F. Volney. 8 vols. París: Bossange frères.

Volney, Constantin-François (1822a): Les ruines, ou Méditation sur les révolutions des empires. On y a joint La loi naturelle. $10^{a}$ ed. París: Bossange frères.

Volney, Constantin-François (1823a): La loi naturelle, ou principes physiques de la morale. In: Constantin-François Volney. Euvres de C.-F. Volney. Vol. 11. Bruselas: Auguste Wahlen, 3-73.

Volney, Constantin-François (1823b): Les ruines, ou Méditation sur les révolutions des empires. In: Constantin-François Volney. Euvres de C.-F. Volney. Vol. 10. Bruselas: Auguste Wahlen.

Volney, Constantin-François (1823c): Les ruines, ou Méditation sur les révolutions des empires. On y a joint La loi naturelle. 13a ed. Bruselas: Auguste Wahlen.

Volney, Constantin-François (1823d): Euvres de C.-F. Volney. 11 vols. Bruselas: Auguste Wahlen.

Volney, Constantin-François (1824): Les ruines, ou Méditation sur les révolutions des empires. Nouvelle édition ornée de figures. París: Baudouin frères.

Volney, Constantin-François (1826a): La loi naturelle, ou Principes physiques de la morale. In: Constantin-François Volney. Euvres de C. F. Volney. Vol. 1. París: Parmantier/Froment, 245-307.

Volney, Constantin-François (1825-1826): CEuvres de C. F. Volney. 8 vols. París: Parmantier/ Froment.

Volney, Constantin-François (1826b): La loi naturelle, ou Principes physiques de la morale; suivie de l'Histoire de Samuel. In: Constantin-François Volney. Euvres choisies de Volney. Vol. 2. París: Baudouin frères.

Volney, Constantin-François (1826c): Les ruines, ou Méditation sur les révolutions des empires. In: Constantin-François Volney. Euvres choisies de Volney. Vol. 1. París: Baudouin frères.

Volney, Constantin-François (1826d): Les ruines, ou Méditation sur les révolutions des empires. In: Constantin-François Volney. Euvres de C. F. Volney. Vol. 1. París: Parmantier/Froment, $1-243$.

Volney, Constantin-François (1826e): CEuvres choisies de Volney. 2 vols. París: Baudouin frères.

Volney, Constantin-François (1827a): La loi naturelle. In: Constantin-François Volney. Euvres choisies de Volney. Vol. 4. La loi naturelle. Samuel. París: Baudouin frères, 1-78.

Volney, Constantin-François (1827b): Les ruines, ou Méditation sur les révolutions des empires. In: Constantin-François Volney. Euvres choisies de Volney. Vols. 1-3. París: Baudouin frères.

Volney, Constantin-François (1827c): Les ruines, ou Méditation sur les révolutions des empires. On y a joint La loi naturelle. 14a ed. Bruselas: Auguste Wahlen.

Volney, Constantin-François (1827d): Euvres choisies de Volney. 6 vols. París: Baudouin frères.

Volney, Constantin-François (1830a): Les ruines, ou méditation sur les révolutions des empires, suivies de La loi naturelle. París/Bruselas: Canongette. 
Volney, Constantin-François (1830b): Les ruines, ou méditation sur les révolutions des empires, suivies de La loi naturelle. París/Bruselas: Libraires associés/Librairie philosophique.

Volney, Constantin-François (1832): Les ruines ou méditation sur les révolutions des empires. On a joint La loi naturelle. Nouvelle édition. París: Lebigre frères.

Volney, Constantin-François (1833): CEuvres choisies de Volney. Les ruines - La loi naturelle Histoire de Samuel - Lettre au docteur Priestley. París: Lebigre frères.

Volney, Constantin-François (1836): Euvres choisies de Volney. Les ruines - La loi naturelle L'Histoire de Samuel. París: Lebigre frères.

Volney, Constantin-François (1837a): La loi naturelle, ou Principes physiques de la morale, déduits de l'organisation de l'homme et de l'univers. In: Constantin-François Volney. CEuvres complètes de Volney. París: Firmin-Didot, 83-98.

Volney, Constantin-François (1837b): Les ruines, ou Méditation sur les révolutions des empires. In: Constantin-François Volney. CEuvres complètes de Volney. París: Firmin-Didot, 9-82.

Volney, Constantin-François (1837c): Les ruines, ou Méditation sur les révolutions des empires, suivies de La loi naturelle. 17a ed. París/Bruselas: Ledentu/Langlet et Cie.

Volney, Constantin-François (1837d): CEuvres complètes de Volney. París: Firmin-Didot.

Volney, Constantin-François (1839a): La loi naturelle, ou Principes physiques de la morale, déduits de l'organisation de l'homme et de l'univers. In: Constantin-François Volney. Euvres complètes de Volney. París: Auguste Desrez, 83-98.

Volney, Constantin-François (1839b): Les ruines, ou Méditation sur les révolutions des empires. In: Constantin-François Volney. CEuvres complètes de Volney. París: Auguste Desrez, 9-82.

Volney, Constantin-François (1839c): CEuvres complètes de Volney. París: Auguste Desrez.

Volney, Constantin-François (1846): Euvres choisies de Volney. Les ruines - La Loi naturelle - L'Histoire de Samuel. Nouvelle édition. París: B. Renault.

Volney, Constantin-François (1868): Les ruines ou Méditations sur les révolutions des empires, suivies de La Loi naturelle. París: Décembre-Alonnier.

Volney, Constantin-François (1870): Les ruines ou Méditations sur les révolutions des empires suivies de La loi naturelle et de l'Histoire de Samuel. París: Garnier frères.

Volney, Constantin-François (1876a): La loi naturelle, ou Principes physiques de la morale, déduits de l'organisation de l'homme et de l'univers. In: Constantin-François Volney. Les Ruines. La loi naturelle. Vol. 2. París: Librairie de la Bibliothèque nationale, 53-106.

Volney, Constantin-François (1876b): Les Ruines. La loi naturelle. Vol. 1. Les ruines, ou Méditation sur les révolutions des empires (Capítulos I-XXII). París: Librairie de la Bibliothèque nationale.

Volney, Constantin-François (1876c): Les Ruines. La loi naturelle. Vol. 2. Les ruines, ou Méditation sur les révolutions des empires (Capítulos XXII-XXIV). París: Librairie de la Bibliothèque nationale, 3-52.

Volney, Constantin-François (1876d): Les Ruines. La loi naturelle. 2 vols. París: Librairie de la Bibliothèque nationale.

Volney, Constantin-François (1989-1998): CEuvres. (Editado por Anne Deneys-Tunney y Henry Deneys) 3 vols. París: Fayard.

Volney, Constantin-François (1989a): La loi naturelle ou Catéchisme du citoyen français. In: Constantin-François Volney. Euvres (Editado por Anne Deneys-Tunney y Henry Deneys) Vol. 1. París: Fayard, 447-499.

Volney, Constantin-François (1989b): Les ruines ou Méditation sur les révolutions des empires. In: Constantin-François Volney. Euvres (Éditado por Anne Deneys-Tunney y Henry Deneys) Vol. 1. París: Fayard, 165-438.

\section{Anexo 2: Catálogo de las principales traducciones de las Ruines (finales del siglo XVIII y siglo XIX)}

Volney, Constantin-François (1791/1792a): Die Ruinen oder Betrachtungen über die Revolutionen der Reiche; und das natürliche Gesetz. (Traducido anónimamente del francés) 1ª ed. Berlín: Friedrich Vieweg. 
Volney, Constantin-François (1791/1792b): The Ruins: or a Survey of the Revolutions of Empires. (Traducido anónimamente del francés) $1^{\text {a }}$ ed. Londres: Boards Johnson.

VolNey, Constantin-François (?/1793): The Law of nature or principles of morality deducted from the physical constitution of mankind and the universe. (Traducido anónimamente del francés) Filadelfia: [s.n].

Volney, Constantin-François (?/1795): The Ruins: or a Survey of the Revolutions of Empires. 2a ed. (Traducido anónimamente del francés) Londres: J. Johnson.

Volney, Constantin-François (?/1796a): The Ruins: or a Survey of the Revolutions of Empires. 3a ed. (Traducido anónimamente del francés) Londres: J. Johnson.

Volney, Constantin-François (?/1796b): The Ruins: or a Survey of the Revolutions of Empires. (Traducido anónimamente del francés) Nueva York: William A. Davis.

Volney, Constantin-François (?/1799): The Ruins, or a Survey of the Revolutions of Empires. (Traducido anónimamente del francés) Filadelfia: James Lyon.

Volney, Constantin-François (?/1800): Le Rovine, ossia meditazione sulle rivoluzioni degl'Imperi. (Traducido anónimamente del francés) 3 vols. Milano: Tipografia Milanese.

Volney, Constantin-François (1817/1817a): Las Ruinas escritas en francés por el señor de Volney (Hoy conde y par de Francia), traducidas conforme a la quinta edición de París; con tres láminas, y con el Catequismo de la ley natural. (Traducido anónimamente del francés) $5^{\mathrm{a}} \mathrm{ed}$. Nueva York: [s.n.].

Volney, Constantin-François (1817/1817b): Meditación sobre las ruinas. [La ley natural, o Principios físicos de la moral]. (Traducido anónimamente del francés) $5^{a}$ ed. París: $\mathrm{M}^{\mathrm{me}} \mathrm{V}^{\mathrm{e}}$ Courcier.

Volney, Constantin-François (1817/1818a): Meditación sobre las ruinas. [La ley natural o Principios físicos de la moral]. (Traducido anónimamente del francés) $5^{\mathrm{a}}$ ed. Londres: Imprenta de Davi[d]son.

Volney, Constantin-François (1817/1818b): Meditación sobre las ruinas. [La ley natural o Principios físicos de la moral]. (Traducido anónimamente del francés) $5^{\mathrm{a}}$ ed. París: Imprenta de M. Richard.

Volney, Constantin-François (1817/1819): Meditación sobre las ruinas. [La ley natural ó principios físicos de la moral deducidos de la constitución del hombre y del universo]. (Traducido anónimamente del francés) $5^{\mathrm{a}}$ ed. Londres: [s.n.].

Volney, Constantin-François (1817/1820a): Las ruinas, ó Meditación sobre las revoluciones de los imperios, obra del célebre francés Volney, traducida del francés. Nueva edición con notas, enriquecida con el Tratado de Ley Natural. (Traducido anónimamente del francés) $5^{\mathrm{a}}$ ed. Perpiñán: José Alcine.

Volney, Constantin-François (1817/1820b): Las ruinas, ó Meditación sobre las revoluciones de los imperios; Va añadida La ley natural. (Traducido del francés por Josef MARCHENA) $5^{\mathrm{a}} \mathrm{ed}$. Burdeos: Imprenta de D. Pedro Beaume.

Volney, Constantin-François (1817/1821): Meditación sobre las ruinas. Las ruinas, ó Meditación sobre las revoluciones de los imperios; por C.-F. Volney, precedidas de una noticia necrológica, por el S. ${ }^{\mathrm{r}}$ Daru. Se halla a continuación La ley natural. (Traducido anónimamente del francés) $5^{a}$ ed. Madrid/París: en casa de Rosa/gran Patio del Palacio Real.

Volney, Constantin-François (1817/1822a): Las Ruinas, escritas en francés por el señor de Volney (Hoy conde y par de Francia.) Y con El Catecismo de La ley natural. Traducidas conforme a la quinta edición de París. (Traducido anónimamente del francés). $5^{\mathrm{a}}$ ed. Nueva York: [s.n.].

Volney, Constantin-François (1817/1822b): Las ruinas, ó Meditación sobre las revoluciones de los imperios Por C.-F. Volney. Va añadida La ley natural. $2^{a}$ ed. trad. (Traducido del francés por Josef Marchena) $5^{a}$ ed. Burdeos: Imprenta de Don Pedro Beaume.

Volney, Constantin-François (1817/1822c): Meditación sobre las ruinas. Las ruinas, ó Meditación sobre las revoluciones de los imperios; por C.-F. Volney. Se halla a continuación La ley natural. (Traducido anónimamente del francés) $5^{a}$ ed. Madrid/París: en casa de Rosa/gran Patio del Palacio Real. 
Volney, Constantin-François (1817/1823): Las ruinas, ó Meditación sobre las revoluciones de los imperios; por C. F. Volney. Se ha añadido La ley natural. (Traducido anónimamente del francés) $6^{\mathrm{a}}$ ed. Madrid: Imprenta de Sancha.

Volney, Constantin-François (1817/1835): Las Ruinas de Palmira, ó Meditación sobre las revoluciones de los imperios: por C.F. Volney. Se ha añadido La ley natural. (Traducido anónimamente del francés) $6^{\mathrm{a}}$ ed. París: Librería Americana de Rosa.

Volney, Constantin-François (1817/1836a): Las Ruinas de Palmira, ó meditación sobre las revoluciones de los imperios. Por C. F. Volney. Se ha añadido La ley natural. (Traducido anónimamente del francés) $5^{a}$ ed. París: Librería Americana de Rosa.

Volney, Constantin-François (1817/1836b): Las ruinas, ó Meditación sobre las revoluciones de los imperios, por C. F. Volney. Se halla a continuación La ley natural comentada por D. B. F. A. D. V. D. N. (Traducido anónimamente del francés) 5a ed. París: [s.n.] (gran Patio del Palacio Real).

Volney, Constantin-François (1817/1836c): Meditación sobre Las ruinas. Las Ruinas, ó Meditación sobre las revoluciones de los Imperios, por C. F. Volney. Se halla a continuación La ley natural. (Traducido anónimamente del francés) 5a ed. París: gran Patio del Palacio Real.

Volney, Constantin-François (1817/1839a): Las ruinas de Palmira, ó Meditación sobre las revoluciones de los imperios. Por C. F. Volney. Se ha añadido La ley natural. (Traducido anónimamente del francés) $5^{\text {a }}$ ed. Zaragoza: Imprenta de D. Felipe Sanz.

Volney, Constantin-François (1817/1839b): Las ruinas de Palmira, ó Meditaciones sobre las revoluciones de los imperios. Por C. F. Volney. Se halla a continuación La ley Natural. (Traducido anónimamente del francés) $5^{\mathrm{a}}$ ed. París: gran Patio del Palacio Real.

Volney, Constantin-François (?/1842): Las ruinas, o Meditación sobre las revoluciones de los imperio. Por C. F. Volney. Añadida La ley natural. $3^{\text {a }}$ ed. trad. (Traducido del francés por Joseph Marchena) París: Imprenta de Panckoucke.

Volney, Constantin-François (1817/1844): Las ruinas ó Meditación sobre las revoluciones de los imperios. Por M. Volney, diputado de la Asamblea Nacional de 1789. Adicionadas con La ley natural. (Traducido anónimamente del francés) $5^{\mathrm{a}}$ ed. Perpiñán: [José Alcine].

VolNey, Constantin-François (1817/1854): Las ruinas ó Meditación sobre las revoluciones de los imperios. Precedidas de su biografía y seguidas de La ley natural por C. F. Volney. (Traducido anónimamente del francés) $5^{\mathrm{a}}$ ed. Madrid: imprenta del editor.

Volney, Constantin-François (1817/1858): Las Ruinas. Las ruinas ó Meditación sobre las revoluciones de los imperios; Por M. Volney, diputado de la Asamblea Nacional de 1789, adicionadas con La ley natural. (Traducido anónimamente del francés) $5^{\mathrm{a}}$ ed. Perpiñán: [José Alcine].

Volney, Constantin-François (1817/ca.1868): Las ruinas de Palmira o Meditación sobre las revoluciones de los imperios; seguida de La ley natural; por C. F. Volney. (Traducido anónimamente del francés) $5^{\mathrm{a}}$ ed. Madrid: Domingo Blanco.

Volney, Constantin-François (1817/1868a): La ley natural ó Principios físicos de la moral, deducidos de la constitución del hombre y del universo. In: Constantin-François Volney. Las ruinas de Palmira ó Meditación sobre las revoluciones de los imperios por M. Volney. (Traducido anónimamente del francés) Vol. 1. Gran Biblioteca del Pueblo. Barcelona: José Codina, 163-209.

Volney, Constantin-François (1817/1868b): Las ruinas de Palmira. In: Las ruinas de Palmira ó Meditación sobre las revoluciones de los imperios por M. Volney. (Traducido anónimamente del francés) T. 1. Gran Biblioteca del Pueblo. Barcelona: José Codina, 7-161.

Volney, Constantin-François (1817/1868c): Las ruinas de Palmira ó Meditación sobre las revoluciones de los imperios por M. Volney. 2 vols. Gran Biblioteca del Pueblo. Barcelona: José Codina.

VolNey, Constantin-François (1817/1869a): Las ruinas de Palmira: meditación sobre las revoluciones de los imperios por Volney. Adicionadas con La ley natural. (Traducido anónimamente del francés) $5^{\mathrm{a}}$ ed. Barcelona: Establecimiento tipográfico-editorial de Manero. 
Volney, Constantin-François (1817/1869b): Las ruinas de Palmira ó Meditación sobre las revoluciones de los imperios por M. Volney. Adicionada con La ley natural. (Traducido del francés por A. O. A.) $5^{\mathrm{a}}$ ed. Barcelona: Sociedad literaria-editorial Guttemberg.

Volney, Constantin-François (1817/1869c): Las ruinas ó meditacion sobre las revoluciones de los imperios, por C. F. Volney, seguida de La ley natural. (Traducido anónimamente del francés) $5^{\mathrm{a}}$ ed. Madrid: Imprenta de Pascual Gracia y Orga.

Volney, Constantin-François (1817/ca.1873): Las ruinas de Palmira ó Meditacion sobre las revoluciones de los imperios. La ley natural. Por M. Volney. $3^{\text {a }}$ ed. trad. (Traducido anónimamente del francés) $5^{\mathrm{a}}$ ed. Gran Biblioteca del Pueblo. Barcelona: José Codina.

Volney, Constantin-François (1817/ca.1880): Las ruinas de Palmira ó Meditación sobre las revoluciones de los imperios. Seguida de La ley natural por C. F. Volney. (Traducido anónimamente del francés) $5^{\mathrm{a}}$ ed. Madrid: Imprenta Plaza Dos de Mayo.

Volney, Constantin-François (1817/1887): Las ruinas de Palmira y La ley natural. Obra escrita en francés por el conde C. F. Volney. Traducida al árabe y a todos los idiomas europeos. (Traducido del francés por Cristóbal Litrán) 5a ed. Barcelona: Establecimiento editorial de V. Acha.

Volney, Constantin-François (1817/1889): Las ruinas de Palmira, La ley natural y La historia de Samuel por el conde de Volney. (Traducido del francés por Emilio Prieto y Villarreal) $5^{a}$ ed. París: Garnier hermanos.

Volney, Constantin-François (1817/ca.1892): Las ruinas de Palmira ó Meditación sobre las revoluciones de los imperios, seguida de La ley natural, por el conde de Volney. (Traducido del francés por A. ZeUgeID) $5^{\text {a }}$ ed. Barcelona: A. Zeugeid.

Volney, Constantin-François (1791/2018): Las ruinas de Palmira. (Traducido del francés por Demetrio Castro) $1^{\text {a }}$ ed. Zaragoza: PUZ.

\section{Anexo 3: Otras obras de Volney}

M. C. [Volney, Constantin-François] (1782): Lettre de M. C. à Messieurs les Auteurs du Journal des Sçavans, sur la Chronologie de différens Peuples anciens, dans un espace qui a pour bornes le Siècle de David \& le Passage de Xercès en Grèce. Le Journal des sçavans. Janvier: 22-40.

Volney, Constantin-François (1787): Voyage en Syrie et en Égypte pendant les années 1783, 1784 et 1785. París: Desenne.

Volney, Constantin-François (1788): Considérations sur la guerre des Turcs et de la Russie. Londres: [s.n.].

Volney, Constantin-François (1794): Simplification des langues orientales, ou la Méthode nouvelle et facile d'apprendre les langues arabe, persane et turque, avec des caractères européens. París: Imprimerie la République.

Volney, Constantin-François (1799b): Leçons d'histoire prononcées à l'école normale, en l'an III de la République française. París: J. A. Brosson.

Volney, Constantin-François (1808b): Chronologie d'Hérodote, conforme à son texte. $1^{\text {a }}$ parte. Supplément à l'Hérodote de Larcher. París: Courcier.

Volney, Constantin-François (1821e): Lettre au Docteur Priestley. In: CEuvres complètes de C.-F. Volney. Vol. 1. París: Bossange frères, 367-384.

Volney, Constantin-François (1822b): Voyages en Égypte et en Syrie. París: Bossange frères.

\section{Anexo 4: Fuentes contemporanéas}

Амat, Felix (1834): Meditaciones del Ilmo. Sr. D. Felix Amat arzobispo que fue de Palmyra, en un supuesto congreso celebrado entre las ruinas de dicha ciudad por procuradores de todas las sociedades civiles y religiosas del mundo con que refuta completamente, la impía fábula que forjó Volney entre aquellas ruinas, y se hace patente con la luz de la razón natural la verdad de la religión cristiana. Madrid: Imprenta que fue de Fuentenebro. 
Baudouin, Alexandre y Baudouin, Charles (1820): Avis. In: Constantin-François de Volney. Les ruines, ou Méditation sur les révolutions des empires. Corrigée de nouveau par l'auteur; on y a joint La Loi naturelle. $6^{\mathrm{a}}$ ed. París: Baudouin frères, s. p.

Berger, Eugène (1853): Volney. Étude sur sa vie et sur ses œuvres. In: Charles-Augustin SAInteBeuve. Causeries du Lundi. Vol. 7. París: Garnier frères, 309-344.

Berger, Eugène (1870): Aperçus sur la vie et les ouvrages de Volney (Extrait des Causeries $d u$ Lundi). In: Constantin-François Volney. Les ruines ou Méditations sur les révolutions des empires suivies de la Loi naturelle et de l'Histoire de Samuel. París: Garnier frères, I-XI.

Bossange, Adolphe (1821): Notice sur la vie et les écrits de C.-F. Volney. In: Euvres complètes de C.-F. Volney. Vol. 1. París: Bossange frères, I-XLIX.

Bureau du Mémorial catholique (1825): De la propagation des livres irréligieux depuis la restauration. Le Mémorial catholique. 2(mai):261-299.

[Calvo y Ayala, Gregorio] (1826): El Acuerdo de esta Real Audiencia en el que celebró en 23 de octubre próximo, obedeció, mandó guardar y cumplir y que se imprimiese y circulase la Real orden de 11 del mismo, comunicada en el 14 por el Excmo. Sr. Gobernador del Consejo, cuyo tenor... [s.l]: [s.n.].

CARbonero y Sol, Léon (1873): Índice de los libros prohibidos por el Santo oficio de la inquisición española, desde esta fecha hasta fin de diciembre de 1872. Madrid: Antonio Pérez Dubrull.

Chamrobert, Paulin Pierre (de) (1829/1834): 1820. Mort du comte de Volney, 25 avril. In: Antoine-Vincent Arnault, François Aubert de Vitry, Jean-Baptiste Bory de SaintVINCENT et al. Éphémérides universelles. Vol. 4. $2^{\mathrm{a}}$ ed. París: Corby, 479-484.

Claretie, Jules (1868): [Notice sur la vie et les œuvres de] Volney. In: Constantin-François de Volney. Les ruines ou Méditation sur les révolutions des empires, suivies de La Loi naturelle. París: Décembre-Alonnier, v-xxxix.

DARU, Pierre (1820a): Discours prononcé à la Chambre des Pairs, dans la séance du 14 juin 1820, par M. le comte Daru, à l'occasion de la mort de M. Le Comte de Volney. Revue Encyclopédique. 7:36-48.

Daru, Pierre (1820b): Notice sur M. Le Comte de Volney. In: Constantin-François de Volney. Les ruines, ou Méditation sur les révolutions des empires. Corrigée de nouveau par l'auteur; on y a joint La Loi naturelle. $6^{a}$ ed. París: Baudouin frères, i-xxj.

Filósofo Arrinconado, El (1823): Cartas escritas en defensa de varias materias eclesiásticas $y$ políticas. Vol. 1. Manresa: Martín Trullán.

Gautier, Théophile (1865): Loin de Paris. París: Michel Lévy frères.

INQUISICIÓN ESPAÑOLA (1805): Suplemento al indice expurgatorio del año de 1790 que contiene los libros prohibidos y mandados expurgar en todos los reynos y señoríos del católico rey de España el Sr. D. Cárlos IV, desde el edictor de 13 de diciembre del año de 1789 hastá el 25 de agosto de 1805. Índice de libros prohibidos de la Inquisición española. Madrid: Imprenta Real.

Jouvin, M. (1799): Examen d'un écrit intitulé Les ruines, ou Méditations sur les Révolutions. Londres: Ph. le Boussonnier \& Co.

Jullien, Marc Antoine, dir. (1819): Nouvelles littéraires et scientifiques. Revue encyclopédique ou analyse raisonnée. $3: 563-604$.

Lemaire, Victoire-Félicité (veuve de Louis Courcier) (1819): Notice des principaux ouvrages de fonds et autres en grand nombre, composant la librairie de $M^{m e} V^{e}$ Courcier, ImprimeurLibraire pour les Mathématiques, la Marine, les Sciences et les Arts. París: $\mathrm{M}^{\mathrm{me}} \mathrm{V}^{\mathrm{e}}$ Courcier.

Meléndez Valdés, Juan (1832): Poesías. París: Librería Hispano-Americana.

M[ARTIN] D[E] N[OIRLIEU], abbé (1823): Réfutation abrégée du livre de Volney intitulé: Les ruines, ou Méditation sur les révolutions des empires. Lovaina: Vanlinthoout et Vandenzande.

Montesquieu (1721/1818): Cartas persianas escritas en francés. (Traducido del francés por José Marchena) Nimes: Imprenta de P. Durand-Belle.

Pastoret, Claude-Emmanuel (de) (1843): Discours de réception du marquis de Pastoret. (24 de agosto de 1820). In: ACADÉMIE FRANÇAISE. Recueil des discours, rapports et pièces diverses lus dans les séances publiques et particulières de l’Académie Française 1820-1829. París: 
Firmin Didot frères, 3-14.

Pillet, Pierre, dir. (1842): Livres espagnols. Bibliographie de la France, ou Journal général de l'imprimerie et de la libraire. 31(41):569.

Priestley, Joseph (1797): The Theological and Miscellaneous Works of Joseph Priestley. Vol. 17. Londres: G. Smallfield.

QUÉRARD, Jean-Marie (1839): La France littéraire.Vol. 10. París: Firmin Didot frères.

Rata Sabia (1892): Las Ruinas de Palmira, per lo Compte de Volney. La Esquella de la torratxa: periódich satírich, humorístich, illustrat y literari. 692:232.

Rédaction du Journal de Paris (25 septembre 1791): Assemblée Nationale. Journal de Paris. 268:1091-1094.

Renouard, Antoine-Augustin (1819): Catalogue de la Bibliothèque d'un amateur. Vol. 1. París: Antoine-Augustin Renouard.

SACRa CONGREgatio Indicis (1819): Index librorum prohibitorum, sanctissimi domini nostri Pii septimi pontificis maximi, jussu editus. Roma: Ex Typographia Rev. Camerae Apostolicae.

Sacra Congregatio Indicis (1822): Decretum. Fer. II. Die 17. Decembris 1821. In: Sacra Congregatio Indicis (1819): Index librorum prohibitorum, sanctissimi domini nostri Pii septimi pontificis maximi, jussu editus. Roma: Ex Typographia Rev. Camerae Apostolicae, $1-3$.

SÉCHÉ, Léon (1899): Volney 1757-1820. Étude suivie du Pamphlet de Volney La Sentinelle du peuple. París: Librairie historique des provinces.

Sirand, Alexandre (1851): Bibliographie de l'Ain. Bourg-en-Bresse: Typographie Milliet-Bottier.

Villaseñor y ACuÑa, Juan (1845): Las Ruinas ó meditación de las evoluciones de los imperios por Volney. Libros impíos. La Censura. I(12):96.

\section{Anexo 5: Fuentes lingüísticas}

Real Academia Española (RAE) (1791): Diccionario de la lengua castellana. $3^{\text {a }}$ ed. Madrid: Joaquín Ibarra.

Real Academia Española (RAE) (1803): Diccionario de la lengua castellana. $4^{\mathrm{a}}$ ed. Madrid: Don Joaquín Ibarra.

Real Academia Española (RAE) (1817): Diccionario de la lengua castellana. $5^{\mathrm{a}}$ ed. Madrid: Imprenta Real.

Real Academia Española (RAE) (1792): Ortografía de la lengua castellana. 7a impresión. Madrid: Ibarra.

Real Academia Española (RAE) (1800): Ortografía de la lengua castellana. $7^{\text {a }}$ impresión. Barcelona: Matheo Barceló.

Real Academia Española (RAE) (1815): Ortografía de la lengua castellana, $8^{\mathrm{a}}$ ed. Madrid: Imprenta Real. 